\title{
Numerical Investigation of Hydrodynamics and Cohesive Sediment Transport in Cua Lo and Cua Hoi Estuaries, Vietnam
}

\author{
Viet Thanh Nguyen ${ }^{1,2}, *$, , Minh Tuan $\mathrm{Vu}^{3}$ and Chi Zhang ${ }^{1}$ \\ 1 State Key Laboratory of Hydrology-Water Resources and Hydraulic Engineering, Nanjing 210098, China; \\ zhangchi@hhu.edu.cn \\ 2 Faculty of Civil Engineering, University of Transport and Communications, Hanoi 100000, Vietnam \\ 3 Faculty of Hydraulic Engineering, Hanoi University of Civil Engineering, Hanoi 100000, Vietnam; \\ tuanvm@nuce.edu.vn \\ * Correspondence: vietthanh@utc.edu.vn; Tel.: +84-913-080-860
}

check for updates

Citation: Nguyen, V.T.; Vu, M.T.; Zhang, C. Numerical Investigation of Hydrodynamics and Cohesive Sediment Transport in Cua Lo and Cua Hoi Estuaries, Vietnam. J. Mar. Sci. Eng. 2021, 9, 1258. https:// doi.org/10.3390/jmse9111258

Academic Editor: Dominic E. Reeve

Received: 12 September 2021

Accepted: 6 November 2021

Published: 12 November 2021

Publisher's Note: MDPI stays neutral with regard to jurisdictional claims in published maps and institutional affiliations.

Copyright: (c) 2021 by the authors. Licensee MDPI, Basel, Switzerland. This article is an open access article distributed under the terms and conditions of the Creative Commons Attribution (CC BY) license (https:// creativecommons.org/licenses/by/ $4.0 /)$.

\begin{abstract}
Two-dimensional models of large spatial domain including Cua Lo and Cua Hoi estuaries in Nghe An province, Vietnam, were established, calibrated, and verified with the observed data of tidal level, wave height, wave period, wave direction, and suspended sediment concentration. The model was then applied to investigate the hydrodynamics, cohesive sediment transport, and the morphodynamics feedbacks between two estuaries. Results reveal opposite patterns of nearshore currents affected by monsoons, which flow from the north to the south during the northeast (NE) monsoon and from the south to the north during the southeast (SE) monsoon. The spectral wave model results indicate that wave climate is the main control of the sediment transport in the study area. In the NE monsoon, sediment from Cua Lo port transported to the south generates the sand bar in the northern bank of the Cua Hoi estuary, while sediment from Cua Hoi cannot be carried to the Cua Lo estuary due to the presence of Hon Ngu Island and Lan Chau headland. As a result, the longshore sediment transport from the Cua Hoi estuary to the Cua Lo estuary is reduced and interrupted. The growth and degradation of the sand bars at the Cua Hoi estuary have a great influence on the stability of the navigation channel to Ben Thuy port as well as flood drainage of Lam River.
\end{abstract}

Keywords: hydrodynamics; suspended sediment concentration; cohesive sediment transport; monsoon; Cua Lo estuary; Cua Hoi estuary

\section{Introduction}

An estuary is defined as the transition zone between land and sea, where the flow and transport of sediment between the river and the sea meet. Estuaries occur in many coastal areas around the world. They play an important role in human life such as providing space for navigation, entertainment, commerce as well as living. However, the estuarine environment contains complex physical processes that are controlled by both natural factors and human activities. Specifically, estuarine morphology is subjected to the impact of a combination of hydrodynamic conditions, the sedimentary environment, sediment supply, and the underlying geology. The continuous interaction between the sedimentary environment and non-linear tidal propagation drives the morphological evolution of tidal basins [1]. Furthermore, the morphological change also affects the hydrodynamic tidal regime and sediment transport particularly leading to changes in the depth of the estuary and in the elevation/volume of inter-tidal areas. Due to the importance of estuaries as well as the complexity of processes in the estuarine, the forecast of the current regime, transport, erosion, and deposition of sediment is an interesting issue attracting many researchers.

One of the main factors that govern the evolution of estuary morphology is cohesive sediment transport. It is not only a concern for water quality in coastal areas and estuaries 
but also represents a concern to engineering problems, such as siltation of navigation channels as well as erosion of river banks and coastal beaches [2]. With the rapid development of computer technology over the past two decades, many numerical models have been developed to predict and understand the complex physical processes in estuaries and coastal zones in general as well as cohesive sediment transport in particular. Hayter and Mehta developed a two-dimensional, depth-averaged, finite element cohesive sediment transport model to predict the movement of cohesive sediments in estuarial waters [3]. A two-dimensional, width-integrated model considering the effect of the bathymetry, the freshwater discharge, tides, salinity, and internal feedbacks between the water currents and the suspended mud was suggested by Guan et al. [4] to describe the dynamics of the water, salinity, and cohesive sediment in the Jiaojiang River estuary. Then, Guan et al. continued to develop a 3D model using a fine resolution grid near the bottom to simulate fluid-mud formation for this estuary [5]. Wu et al. applied a refined, three-dimensional, layer-integrated mathematical model for predicting the flow and cohesive sediment transport processes in the Humber Estuary, UK [6]. Cancino and Neves used the 3D-baroclinic numerical model to discover cohesive sediment transport and its dependency on 3D flow features in the Western Scheldt and Gironde estuaries [7]. Cheviet et al. carried out 3D simulations of cohesive sediment transport in the Loire estuary, France, using the TELEMAC-3D model [8]. A laterally averaged two-dimensional numerical model was calibrated and verified based on the field data at various stations and showed good agreement to reproduce the prototype water surface elevation, currents, and salinity distributions in the Tanshui River estuarine system, Taiwan [9]. Lumborg and Windelin succeeded in simulating cohesive sediment dynamics of Rømø Dyb tidal area using the model of MIKE 21 MT [10]. Pandoe and Edge presented the simulation results of the cohesive sediment transport from the mouth of the Mississippi River along the north shore of the Gulf of Mexico towards and along the Texas coast by applying the 3D-hydrodynamic-baroclinic circulation model [11]. A mud transport model for the Scheldt estuary was developed by Kessel et al. [12]. Franz, Pinto [2] used the MOHID water modeling system to investigate the main factors that influence the cohesive sediment dynamics in an estuarine system composed of large mudflats (Tagus estuary, Portugal). Recently, Dong et al. applied the TELEMAC-2D hydrodynamic module and the sediment module SISYPHE in the TELEMAC model to discover the morphological evolution of the Lingdingyang estuary where cohesive sediment is dominant [13]. Ganju et al. used sediment flux data for calibrating an estuarine geomorphic model for Suisun Bay, California, by ROMS and guarantees that modeled geomorphic evolution will not exceed the actual supply of sediment from the watershed and seaward sources during the calibration period. Giardino et al. used a two-dimensional hydrodynamic model coupled to a morphodynamic model in the IJzer Estuary, Belgium; the models were calibrated with means of field data. The results indicated that tidal pumping was recognized as the main driving mechanism of sediments inside of Ijzer estuary [14]. A 3D baroclinic model of 9-node quadrilateral elements with second-order accuracy for hydrodynamics and cohesive sediment transport in the Pearl River estuary. The model was verified with the field data of water levels, tidal flows, salinities, and suspended sediment concentrations. The numerical results are in good agreement with the field data [15].

In Vietnam, the application of numerical models to predict the hydrodynamic and cohesive sediment transport in estuaries also began to be popular after the first decade of the 21st century. Huan et al. used the wave, flow, and mud transport modules of Mike 21 by DHI to simulate the sediment transport in the Bach Dang Estuary, Vietnam. Under both fair and stormy weather conditions, a strong south-directed flow was generated on the Nam Trieu channel and the eastern area of Lach Huyen estuary. Moreover, mud transport by waves during both fair and stormy weather conditions was modeled with reasonable accuracy [16]. In addition, Nguyen et al. applied a coupled model combining MIKE 21HD and MIKE 21SW with a model of cohesive sediment transport to understand the mechanism of back siltation in the navigation channel in the Dinh An estuary $[17,18]$. Their research results showed that the back siltation is caused to a large extent by the low current velocity 
of the secondary ocean circulation, which often occurs in the curvature segments of the channel. When flow passes through the channel, the decreases in the current velocity and the sediment transport capacity contribute to the settlement of suspended sediment in the channel. In order to understand the mechanism of cohesive sediment transport along the coast of the Mekong River Delta, Vinh et al. used the Delft3D model to simulate sediment transport from Can Tho, My Thuan, and Soai Rap to the South China Sea [19]. The results of their study demonstrated that the southeast waves enhance the concentration all along the Mekong River Delta, while the south and southwest waves cause coastal erosion and higher suspended sediment concentrations in front of the southern delta. Using the Delft3D numerical model, Thanh et al. also carried out a study of suspended sediment dynamics on the Mekong River Delta shelf. The seasonal suspended sediment dynamics influenced by salt concentration, wave conditions, and sediment properties were described more clearly in their study [20]. Recently, Tu et al. investigated sediment transport and morphodynamic processes on the estuaries and coastal zone of the Vietnamese Mekong River Delta by using a well-calibrated Delft3D-4 model for a 10-years period simulation. Their results showed that the influences of upstream sediment reduction and large-scale sand extraction would induce substantial modifications to the subaqueous delta region. Besides anthropogenic action, the sediment volume and spatial distribution were affected greatly by monsoonal variation [21].

The estuaries in central Vietnam are under the influence of monsoon waves in the East Sea. Hung et al., used a high-resolution hydrodynamic model (Delft3D) fully coupled with wave and sediment transport models to investigate the factors controlling the morphology in the Nhat Le estuary. The models were calibrated and verified by observation data measured in dry and wet seasons in 2018. The results suggested that wind-wave have a significant influence on sediment transport and river morphology with the effect accounting for nearly $95 \%$ whereas river discharge and tide play minor roles [22]. Anh et al. also applied Delft 3D to simulate the hydrodynamic and sediment transport at Cua Lo Inlet in Quang Nam province. The results showed that ebb current and wave-induced current during the Northeast monsoon season are the main dynamic factors for south spit elongation and inlet morphological changes [23]. The Delft3D model was used to simulate these processes including flood, wave, circulation models, sediment transport, and morphology change in Cua Dai River mouth, Hoi An city, Quang Nam Province, Viet Nam. The computed result showed qualitative agreement with field site observation. The results indicated that the formation of sand bar and terrace at the Cua Dai river mouth was reproduced in flood season [24].

The main objective of this paper is to set up a coupled two-dimensional model for the hydrodynamics, wave, and cohesive sediment transport in the Cua Lo and Cua Hoi estuaries, Nghe An province, Vietnam. The model was calibrated and verified using field data between 2016 and 2019, respectively. The modeling results help to elucidate the influence of the main forces (e.g., tides, river input, and seasonal variation of wave climate) on the hydrodynamics and the cohesive sediment transport process as well as their interactions between Cua Lo and Cua Hoi estuaries.

\section{Study Area}

Cua Lo and Cua Hoi estuaries are located in Nghe An Province, Vietnam. The coastline from Cua Lo to Cua Hoi is about $9.5 \mathrm{~km}$ long. Cua Lo estuary is the most important estuary while Cua Hoi is the largest estuary in Nghe An province (Figure 1). 


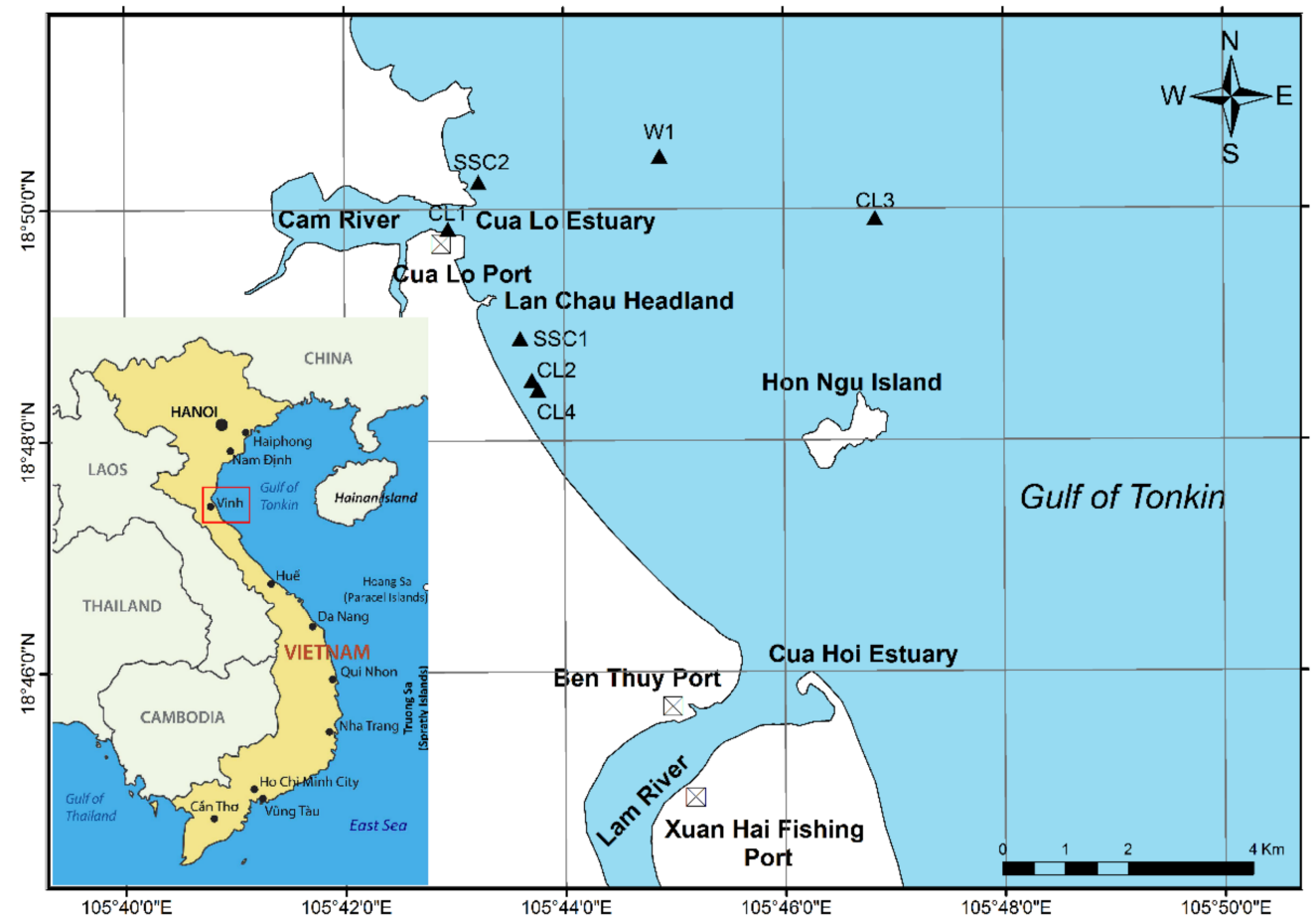

Figure 1. Location of the study area.

Cua Lo Port is located in the Cua Lo estuary of Cam River and it is a modern key project of special significance in economic development not only to Nghe An but also to Laos and northeastern Thailand. The existing port includes six berths for mooring vessels of 10,000 to 20,000 DWT. Ben Thuy port and Xuan Hai fishing port are located in the Cua Hoi estuary of Lam River for mooring vessels of 2000 DWT and fishing ships of 1000 $\mathrm{CV}$, respectively. Cua Lo and Cua Hoi estuaries are typical estuaries appearing in the Central region of Vietnam, which is known as the "narrow shape of sand spit estuary" [18]. The south jetty in the Cua Lo estuary was constructed from 1993 to 1997 with a length of $1003 \mathrm{~m}$ to prevent sedimentation due to sediment transport from the south to the Cua Lo navigation channel. The north jetty was constructed in 2010 with a length of $375 \mathrm{~m}$ to reduce sedimentation due to sediment transport from the north to the navigation channel. The straight coastline from Cua Lo estuary to Cua Hoi estuary is disturbed by the Lan Chau rocky headland which is about $1.5 \mathrm{~km}$ south of Cua Lo estuary.

Wind data recorded at Hon Ngu Island station with an interval time of $3 \mathrm{~h}$ from 1962 to 2020 show that the wind regime is divided into two major seasons-NE monsoon and SE monsoon [25]. The maximum wind speed in the north-northeast (NNE) reached $56 \mathrm{~m} / \mathrm{s}$ on 1 October 1964. Wind during 1962-2020 indicated that the main wind direction is north (N) $(25.85 \%)$, NE $(7.51 \%)$ in the winter, changing to the south (S) $(8.75 \%)$, SE $(9.25 \%)$ in the summer (Figure 2). 


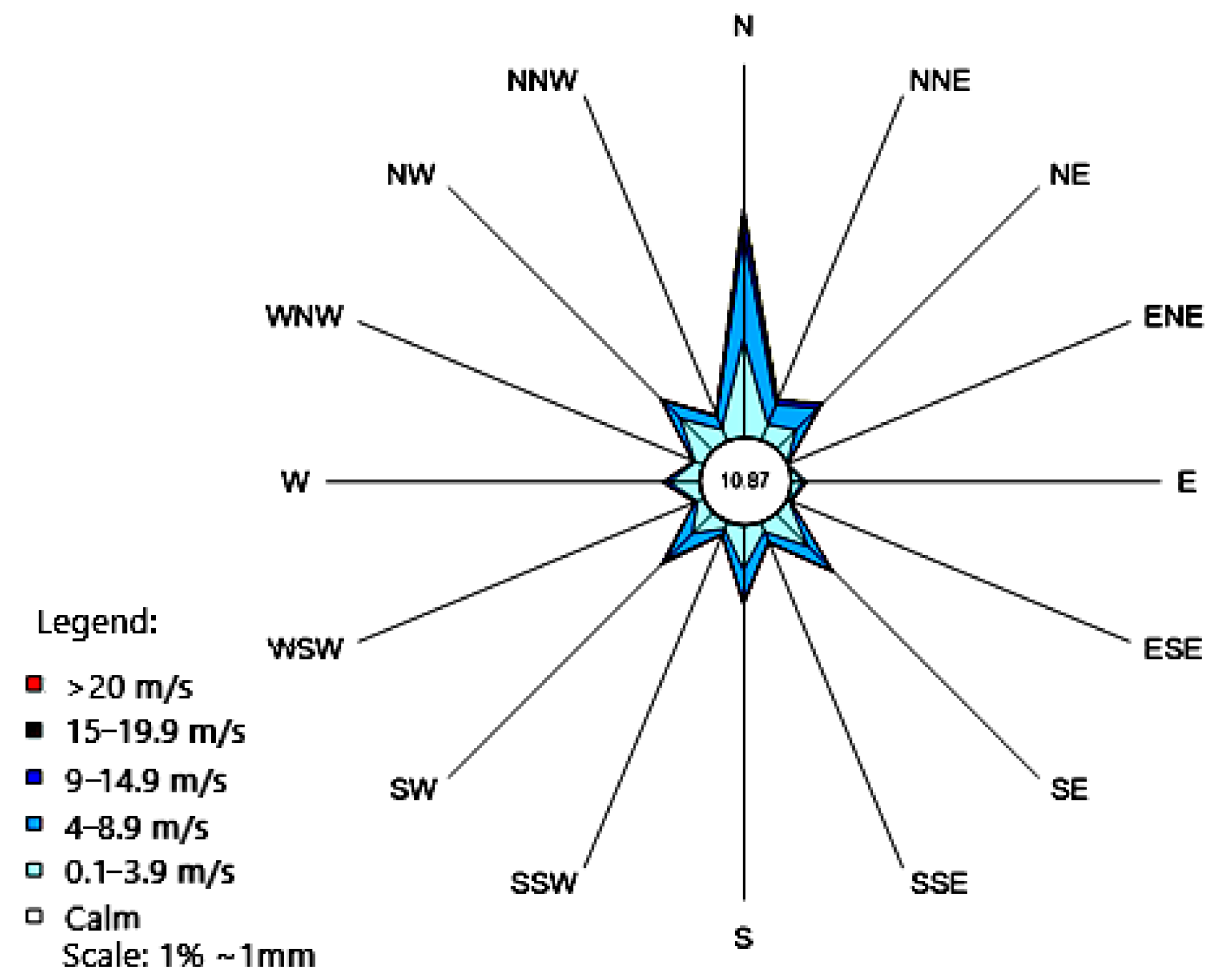

Figure 2. Wind rose in Hon Ngu Island station.

The tidal regime in the study area is semi-diurnal with tidal ranges from 1.0 to 3.59 $\mathrm{m}$ [26]. In the past, the Cam River flow also played an influential role in the formation and existence of tidal creeks in front of Cua Lo port, but this influencing factor is now considered too small due to the presence of the Nghi Quang dam upstream. The nearshore current speed in Cua Lo coastal area measured in December is $0.65 \mathrm{~m} / \mathrm{s}$ in the northwest direction (this is also the time when the area is most affected by the NE monsoon).

Wave regime in the coastal region from Cua Lo to Cua Hoi estuaries generally depends on the wind regime. The prevailing wave in the NE monsoon is NE and N wave with an average wave height ranging from 0.7 to $1.0 \mathrm{~m}$. The prevailing SE monsoon wave is in the SE and SW direction. The maximum wave height observed at Hon Ngu station during tropical storm NANCY (18 May 1982) was $6.0 \mathrm{~m}$. The analysis results of many years of monitoring data show that the frequency of waves occurs as follows: NE waves account for $18.4 \%$, N wave for $15.42 \%$, SE wave for $7.59 \%$, and SW waves for $5.16 \%$, respectively [25]. Offshore wave data from NOAA at the point $19^{\circ} \mathrm{N}, 106^{\circ} 15^{\prime} \mathrm{E}$ during the period from 1997-2016 plotted are shown in Figure 3. The main wave direction is NE with a maximum wave height of about $4.5 \mathrm{~m}$.

The coast from Lan Chau rocky headland to the north bank of Cua Hoi estuary is about $8 \mathrm{~km}$ with a sand-mud beach with fine sand distribution in the dry beach and nearshore. A thin mud layer on the surface was found in the submerged area. Outside the shoreline is a mud distribution of about $50-100 \mathrm{~m}$. Seabed sediment characteristics were collected from TEDIPORT [25]. From 54 samples at locations shown in Figure 4, the testing of grain diameter analysis result indicated that the seabed is composed of almost clay and mud, and the median diameter of sediment is presented in Figure 5. On the other hand, dredging material in the navigation channel to Cua Lo port indicated that the surface of the seabed was almost mud distribution. 




Figure 3. Wave rose from NOOA (1997-2016).

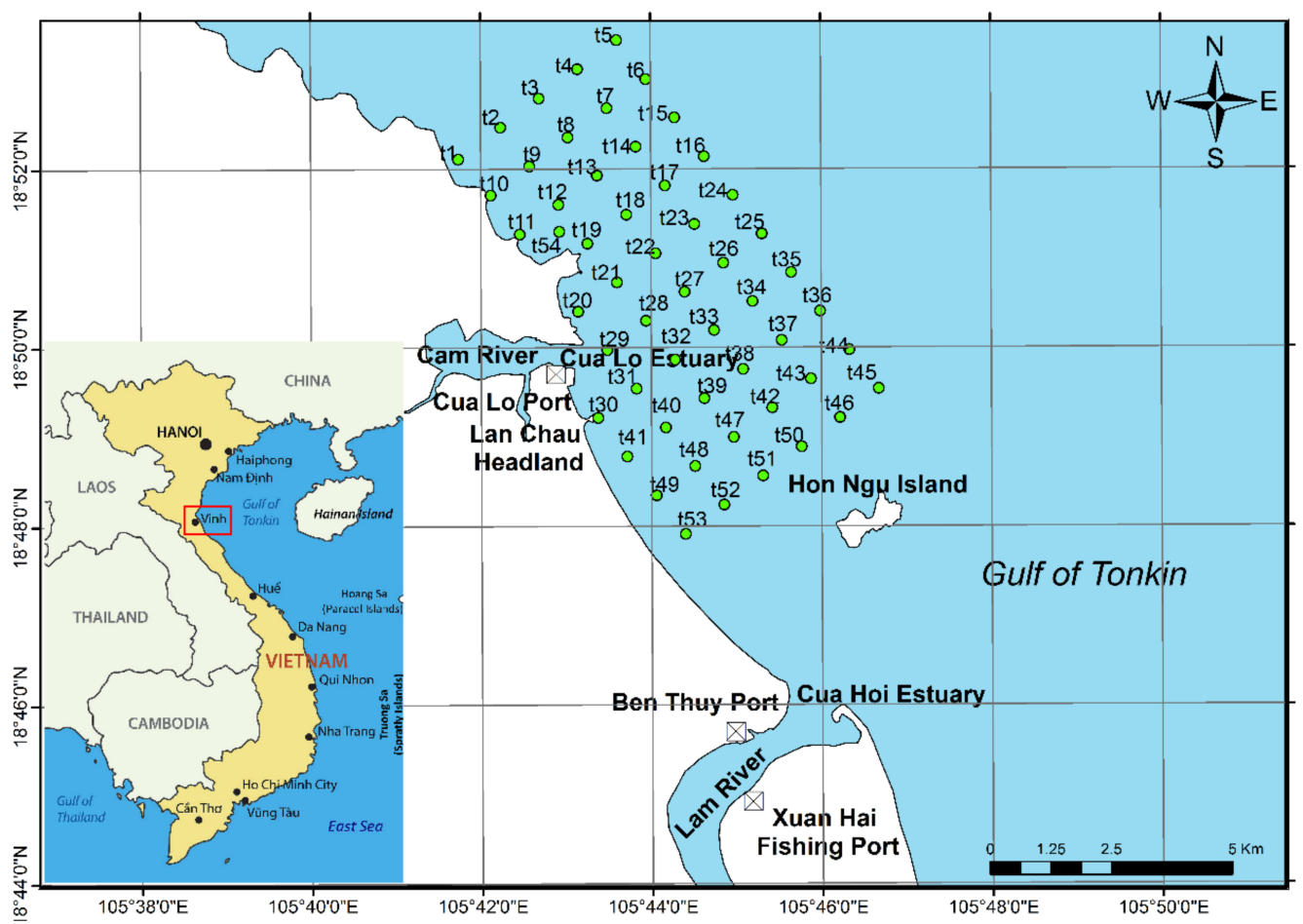

Figure 4. Location of seabed sediment samples. 


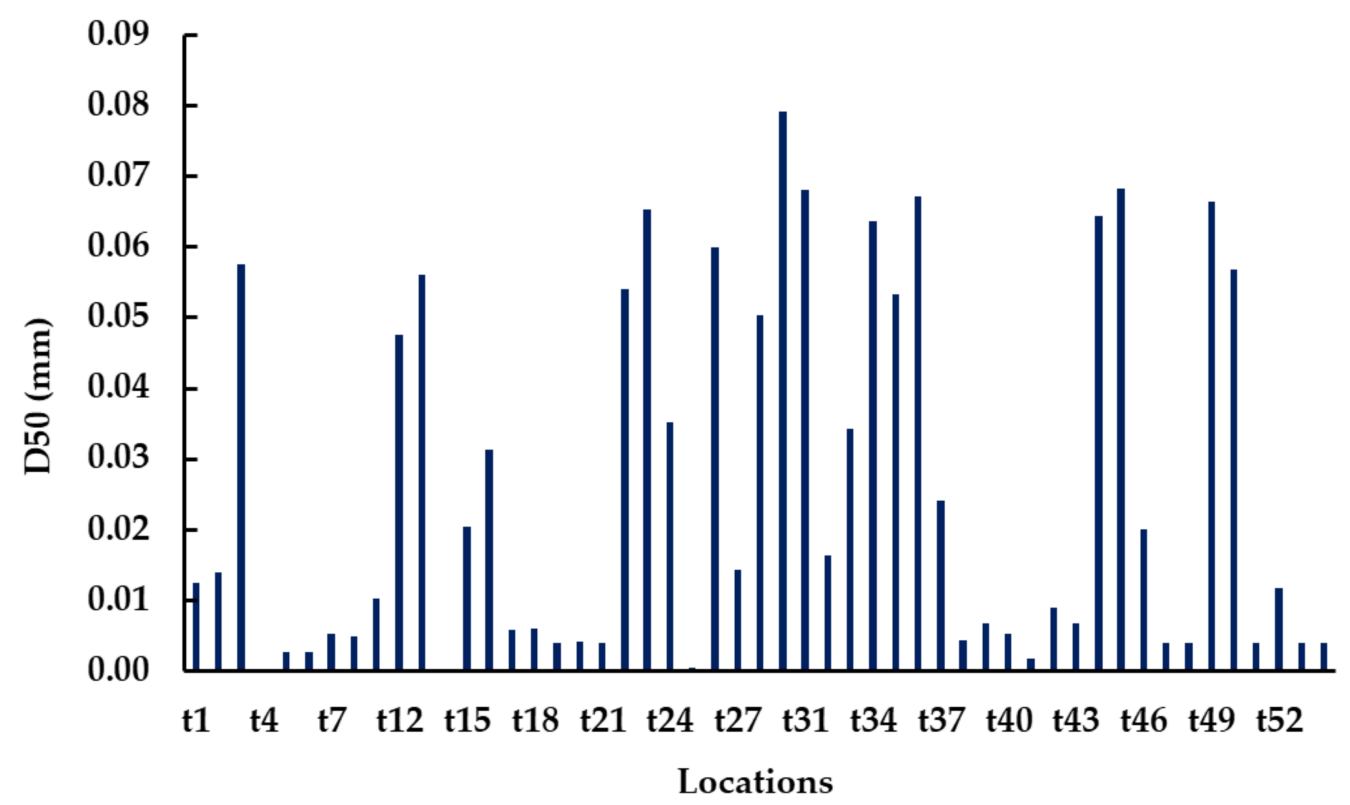

Figure 5. Distribution of mean seabed sediment diameter, $\mathrm{D}_{50}$.

\section{Methods}

\subsection{Hydrodynamic Model}

In this study, the MIKE 21/3 couple model FM including Mike 21 Hydrodynamic Model (HD) and Spectral Wave (SW) modules was used. The scientific details of Mike 21HD were introduced by DHI [27]. The Mike 21HD simulation uses a domain defined by a coastal area located far from Cua Lo estuary (about $8 \mathrm{~km}$ to the north) and far from the Cua Hoi estuary (about $6 \mathrm{~km}$ to the south) (Figure 6). The river boundaries are the Cam and Lam Rivers; in the Cam River, the boundary is far from the Cua Lo estuary (about 2 $\mathrm{km}$ ) and in the Lam River the boundary is far from Cua Hoi (about $3.5 \mathrm{~km}$ ). River flow from the Cam River in the Cua Lo estuary can be ignored due to the presence of the Nghi Quang dam. During storms or high tide, the Nghi Quang dam gate is closed to prevent the saline water from flowing into the river. The upstream boundary in the Cua Hoi estuary is located not far from the river mouth. Both of these two boundaries are influenced by tidal regimes, therefore, tidal levels were used in these boundaries.

The study area bathymetry was surveyed in 2016. All elevations were expressed in meter Chart Datum. The model domain consists of 6300 nodes and 12,000 elements as generated by Mike 21 Mesh Generator and the grid in the nearshore area is finer than in the offshore area. The maximum grid area offshore is $200.000 \mathrm{~m}^{2}$ where in the nearshore and estuaries areas the grid ranges from $100 \mathrm{~m}^{2}$ to $1000 \mathrm{~m}^{2}$.

In the numerical model, the bed resistance is defined by the Manning number. It is variable due to water depth $[28,29]$. The calibration process defines the final Manning number in the domain based on drag coefficient and water depth [29]. Horizontal eddy viscosity is defined by the Smagorinsky model with a constant coefficient of 0.28 .

The observed wind data recorded in the Hon Ngu Island station is used with an interval time of $3 \mathrm{~h}$. This varies in time and is constant along the model boundary. The wave radiation type is used from the SW simulation. The observation data of water levels from Cua Lo and Cua Hoi stations are two upstream boundaries. In the sea boundary, the tidal levels recorded in Hon Ngu Island and offshore of Cua Lo stations are used. Along these boundaries, the linear interpolation values are used and vary in time. The salinity data in the study area are very rare. Salinity distribution of seawater in the South China Sea ranging from 34-35 PSU was studied and presented by Qu et al. [30]. Moreover, according to Qu et al., the salinity in the Gulf of Tonkin is almost constant over the entire sea surface. Therefore, two boundaries upstream of the Cam River and Lam River, 25 and 30 PSU, are assumed, respectively. Sea boundaries the constant value of 35 PSU is used. Other 
parameters of the hydrodynamic model follow the suggested model values such as depth correction, standard flood and dry, and Coriolis force.

The calibration process of the Mike 21HD will be carried out based on the observation data from 15 to 30 November 2016 in the NE monsoon; while this model will be verified from 15 to 30 March 2019 in the SE monsoon.

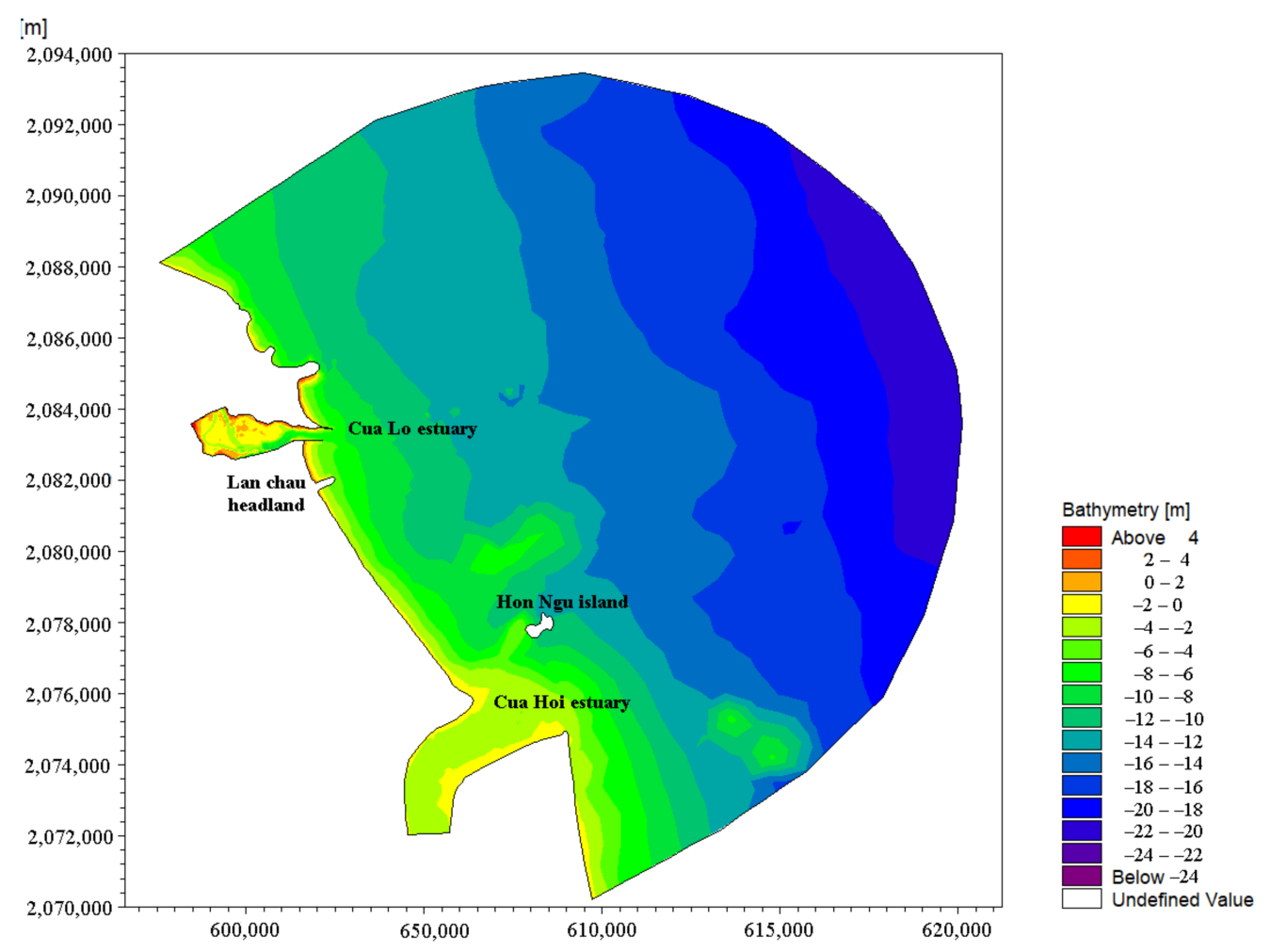

Figure 6. Bathymetry of study area.

\subsection{Wave Model}

The Mike 21 SW model was selected in the Couple Model in MIKE 21/3. Mike 21 SW uses spectral wave model to simulate wave transformation [31]. The fully spectral formulation was used in the stationary mode. A spectral-form empirical formula was used in the initial conditions type. The JONSWAP fetch growth expression was applied with a wave fetch of $160 \mathrm{~km}$ and the maximum peak frequency was $0.4 \mathrm{~Hz}$. JONSWAP parameters used the default values. Offshore wave parameters were based on the data collected from NOOA.

The wave model was coupled with the hydrodynamic model and used the observation wind data in Hon Ngu Island station for the offshore boundary condition. The Mike 21SW is calibrated by adjusting the Nikuradse roughness length $k_{s}$ which is a function of the median grain size $\mathrm{D}_{50}$ in the study domain [29].

\subsection{Mud Transport Model}

The mud transport model Mike 21 MT was used in the Couple Model in MIKE 21/3, the model setup has been estimated by the different site-specific parameters required [32]. A description of the Mike 21 MT was presented by Lumborg and Windelin [10].

The suspended sediment concentration (SSC) in upstream boundaries such as Cua Lo and Cua Hoi stations was assigned with a constant value. These values will be adjusted during calibration. In both boundaries, a series of SSC will be applied during the simulation to obtain a good agreement between observed and simulated results. However, the SSC in the NE monsoon is higher than in the SE monsoon. At the sea boundary, the zero SSC was applied. The critical shear stresses for erosion $\left(\tau_{c e}\right)$ and deposition $\left(\tau_{c d}\right)$ are two sensitive 
parameters of the result of the Mike 21MT model, for which a series of calibrations will be performed to define these parameters.

For the best description of the vertical variation of the near-bed physical characteristics, a model consisting of two layers was selected. The characteristics of these layers have been varied horizontally in order to describe the different erosion and deposition characteristics that can occur in the study area. On the other hand, a number of parameters describing the settling velocity, deposition, and erosion processes were estimated based on the literature which describe in detail the Mike 21 MT module [32], Van Rijn [33], and Parchure and Mehta [34]. The final set of parameters will be obtained by calibration processes.

\subsection{Model Calibration and Verification}

Models were calibrated and verified based on the observation data. The results of each run were compared with observation data and then the model performance was assessed with the mean absolute error (MAE) and root mean square error (RMSE) between observed and simulated data [35]. The MAE is the mean of the absolute values of all differences between simulated and observed values:

$$
\text { MAE }=\frac{1}{n} \sum_{n}^{1} \operatorname{Abs}(\text { Simulated }- \text { Observed })
$$

The RMSE is calculated by summing the square of the difference between the two, then taking the square root of the total and dividing it by the number of records.

$$
\text { RMSE }=\sqrt{\frac{1}{n} \sum_{n}^{1}(\text { Simulated }- \text { Observed })^{2}}
$$

Both MAE and RMSE provide a measure of variance between observed and simulated results and the calibrated parameters will be evaluated using both methods.

The first simulation from 15 to 30 November 2016 was calibrated by observation data. The calibration results are shown in Table 1 and indicate that the three models are in general consistent with the observation data.

Table 1. RMSE and MAE for model calibration (from 15th to 30th, November 2016).

\begin{tabular}{ccccc}
\hline Parameters & RMSE & Difference (\%) & MAE & Difference (\%) \\
\hline Water level at CL1 $(\mathrm{m})$ & 0.05 & 2.21 & 0.04 & 1.83 \\
Current speed at CL1 $(\mathrm{m} / \mathrm{s})$ & 0.11 & 20.54 & 0.07 & 13.60 \\
Current direction at CL1 $\left(^{\circ}\right)$ & 81.71 & 27.18 & 58.78 & 19.55 \\
Wave height at W1 $(\mathrm{m})$ & 0.39 & 13.13 & 0.27 & 9.12 \\
Wave period at W1 $(\mathrm{s})$ & 1.38 & 22.46 & 1.20 & 19.59 \\
Wave direction at W1 $\left(^{\circ}\right)$ & 11.41 & 17.07 & 7.02 & 10.50 \\
SSC at SSC1 $(\mathrm{g} / \mathrm{L})$ & 0.03 & 24.15 & 0.03 & 19.26 \\
SSC at SSC2 $(\mathrm{g} / \mathrm{L})$ & 0.02 & 17.53 & 0.02 & 14.82 \\
\hline
\end{tabular}

The model calibration results suggest a set of model parameters, including the Manning number for the HD, the Nikuradse roughness length for the SW, and the near-bed parameters for the MT models. The main parameters of the models were chosen as Manning's number (M) ranges from 5 to $52 \mathrm{~m}^{1 / 3} / \mathrm{s}$ for the Mike 21HD model. The Nikuradse roughness length $\mathrm{k}_{\mathrm{s}}$ ranges from 0.024 to $0.045 \mathrm{~m}$ for the SW model (Figure 7). These two bottom frictions $\left(\mathrm{M}, \mathrm{k}_{\mathrm{s}}\right)$ are related and both depend on the median grain diameter of sediment $\left(D_{50}\right)$, and define preliminary values for these two quantities based on the in-site conditions [29]. 
'm]

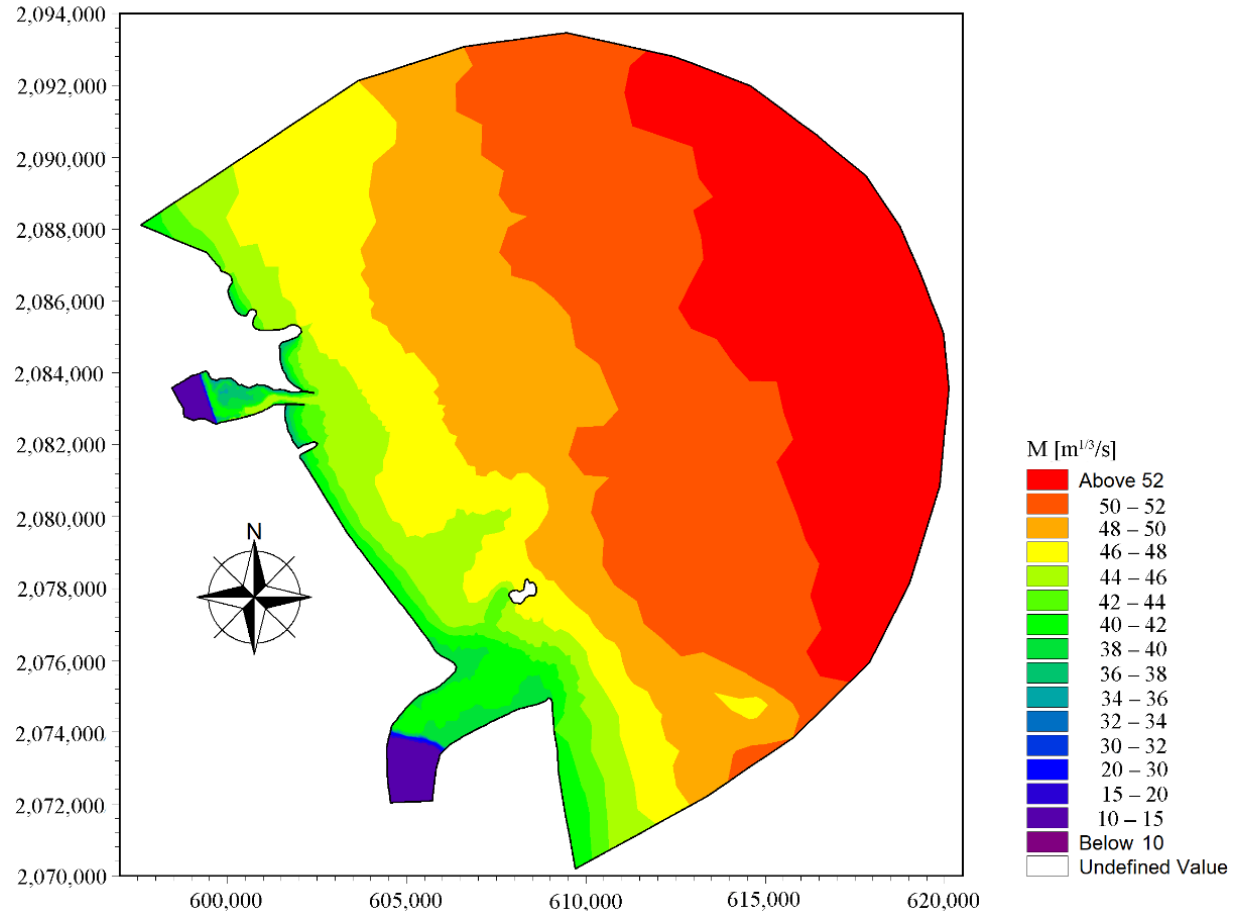

(a)



(b)

Figure 7. Distribution of Manning's number and Roughness length $\left(\mathrm{K}_{\mathrm{S}}\right)$. (a) Manning's number $(\mathrm{M})$; $(\mathbf{b})$ roughness length $\left(\mathrm{K}_{\mathrm{s}}\right)$.

The hydrodynamic model was calibrated with observation data of water level and current, and the results showed that the RMSE was only $2.21 \%$ for water level, $20.54 \%$ for current speed, and $27.18 \%$ for current direction, while MAE were $1.83 \%$ for water level, 
$13.60 \%$ for current speed, and $19.55 \%$ for current direction, as shown in Table 1, Figures 8 and 9 . The result indicated that the simulation water level was very close to the observation data both of phase and amplitude.

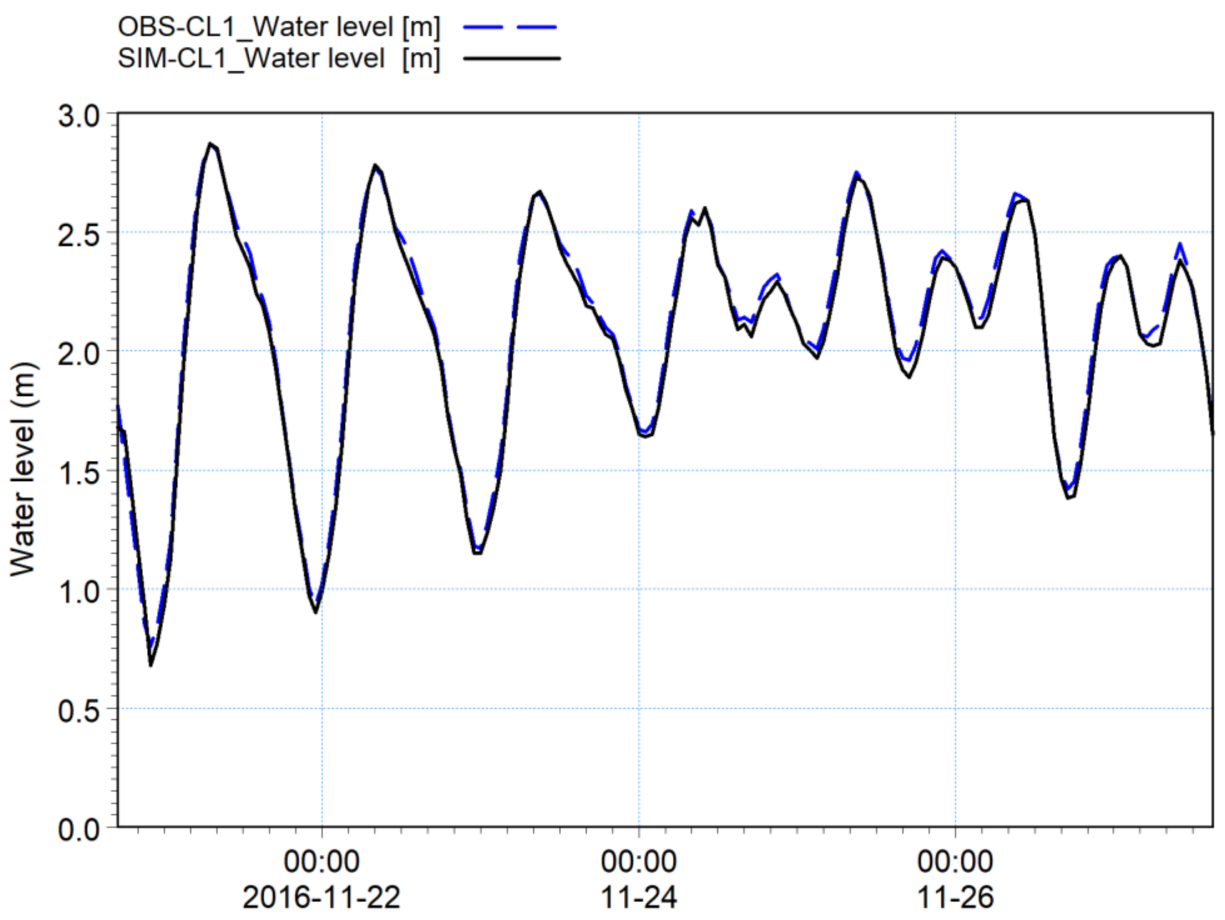

Figure 8. Comparison of observed and simulated water level at station CL1 during calibration.
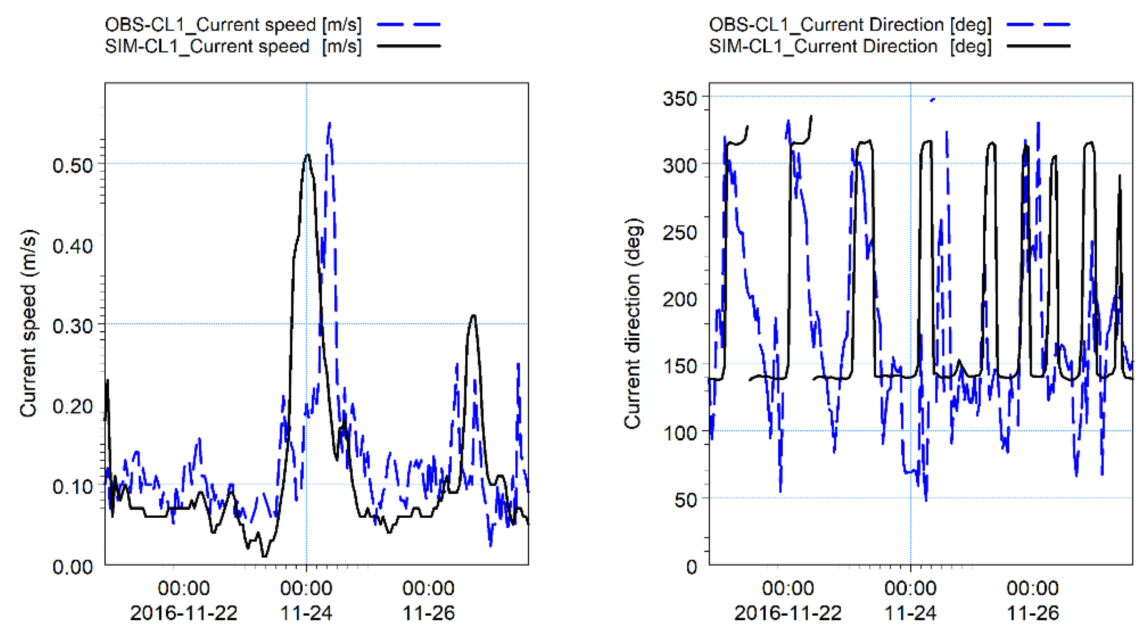

Figure 9. Comparison of observed and simulated current speed and direction at station CL1 during calibration.

The current speed of simulation in Figure 9 showed the same speed amplitude but a difference from the phase. This can be explained due to the observation location under the open type of berth with many concrete piles. The models cannot simulate the influence of piles structures of berth induced the lag of phase. The simulation results also indicated the difference in the current direction.

The spectral wave model was calibrated by wave observation data, and the results indicated that the RMSE were only $13.13 \%$ for wave height, $26.14 \%$ for wave period, and $24.07 \%$ for wave direction, while MAE were $9.12 \%$ for wave height, $26.14 \%$ for wave period, and $24.07 \%$ for wave direction (Table 1). A comparison of simulation results and observation data is shown in Figure 10. 

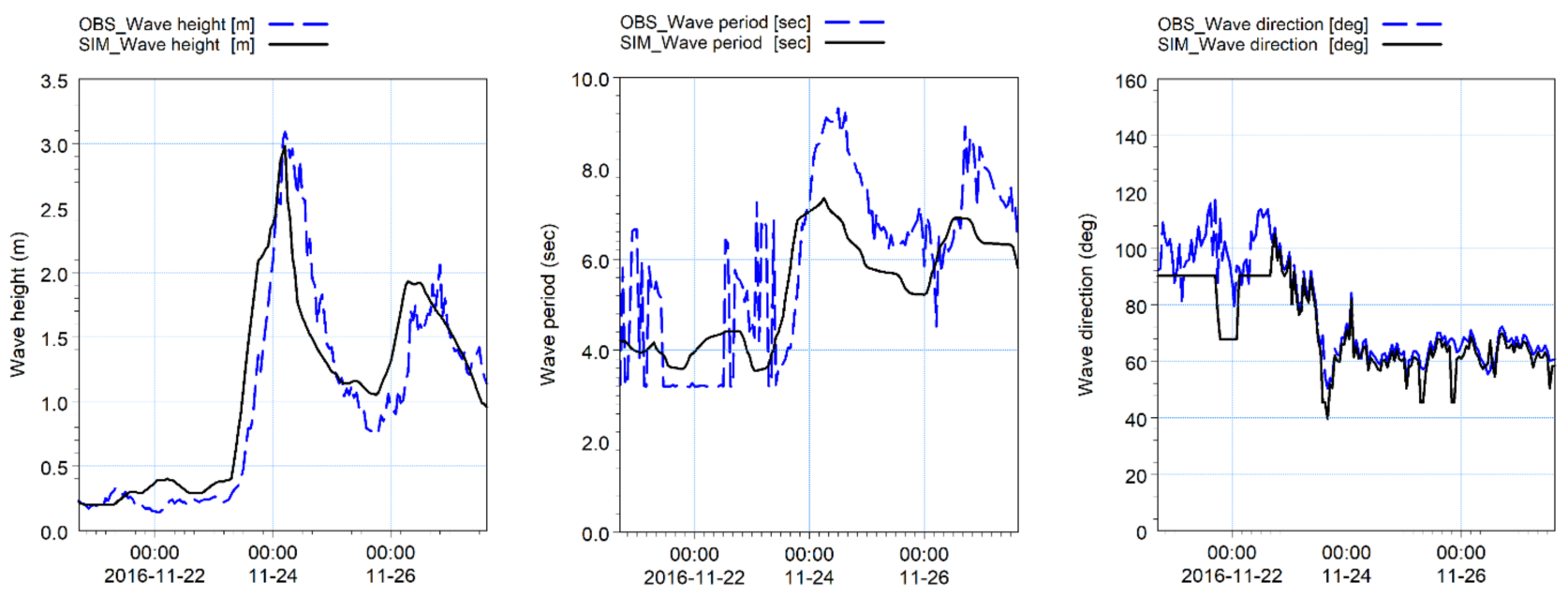

Figure 10. Comparison of observed and simulated wave height, period, and direction at station W1 during calibration.

The calibration of the mud transport model proposes a series of input data for bottom layers, settling velocity, dispersion coefficient, due to the complexity of the series parameters.

For the purpose of finding suitable seabed parameters of the model, the model calibration process was performed by selecting a series of input data. Below is a description of that selection process.

The settling velocity of the suspended sediment is dependent on the suspended sediment concentration and the shear stress in the water column [36]. However, no significant relationship between the concentration and the shear stress has been obtained in the study area. The results indicate that the high settling velocities appear in the river mouth segment of estuaries, and it also shows that the settling velocity is suitable with Stocks' law with the median sediment diameter of $d_{50}$ ranging from 2.0-4.0 $\mu \mathrm{m}$ (Figure 11).

The critical shear stress for deposition $\left(\tau_{c d}\right)$ has not been measured in the Dinh An estuary area, so this parameter is treated as a calibration factor. However, literature values originating from laboratory studies have been found to support the calibration. Krone found $\tau_{c d}$ values at $0.06-0.078 \mathrm{~N} / \mathrm{m}^{2}$ [37] and Mehta and Partheniades found values of $\tau_{c d}$ at $0.18-1.1 \mathrm{~N} / \mathrm{m}^{2}$ [38]. Thanh found $\tau_{c d}$ values at 0.2 to $0.8 \mathrm{~N} / \mathrm{m}^{2}$ for the Dinh An estuary [18]. The values applied in this context vary in the study area from 0.02 to 0.06 $\mathrm{N} / \mathrm{m}^{2}$. The variations in $\tau_{c d}$ are due to the different sediment characteristics in the area.

The critical shear stress for erosion $\left(\tau_{c e}\right)$ is a required value for setting up the model. It also has not been measured and no previous study mentioned this parameter in the study area. Therefore, the model setup is focused on choosing the $\tau_{c e}$ values controlled by the water depth, inundation time, and sediment characteristics. The values applied in this study vary from 0.25 to $1.0 \mathrm{~N} / \mathrm{m}^{2}$ for the first layer. A constant value of $5.0 \mathrm{~N} / \mathrm{m}^{2}$ is applied to the hard mud of the second layer in order to artificially prevent erosion from this layer.

The erosion coefficient (E) is a calibration factor used to control the overall level of erosion. Parchure and Mehta reported values of $0.67 \times 10^{-5}-0.3 \times 10^{-4} \mathrm{~kg} / \mathrm{m}^{2} / \mathrm{s}$ [34]. Van Rijn suggested values varying from $5 \times 10^{-7}$ to $5 \times 10^{-6} \mathrm{~kg} / \mathrm{m}^{2} / \mathrm{s}$ [33]. A value of $3 \times$ $10^{-6} \mathrm{~kg} / \mathrm{m}^{2} / \mathrm{s}$ was applied in the Tanhui River estuarine system of Taiwan [9]. In this study, the erosion coefficients were calibrated in the range from $3 \times 10^{-6}$ to $6 \times 10^{-6} \mathrm{~kg} / \mathrm{m}^{2} / \mathrm{s}$ for the first layer and from $0.4 \times 10^{-4}$ to $0.8 \times 10^{-4} \mathrm{~kg} / \mathrm{m}^{2} / \mathrm{s}$ for the second layer, respectively. 


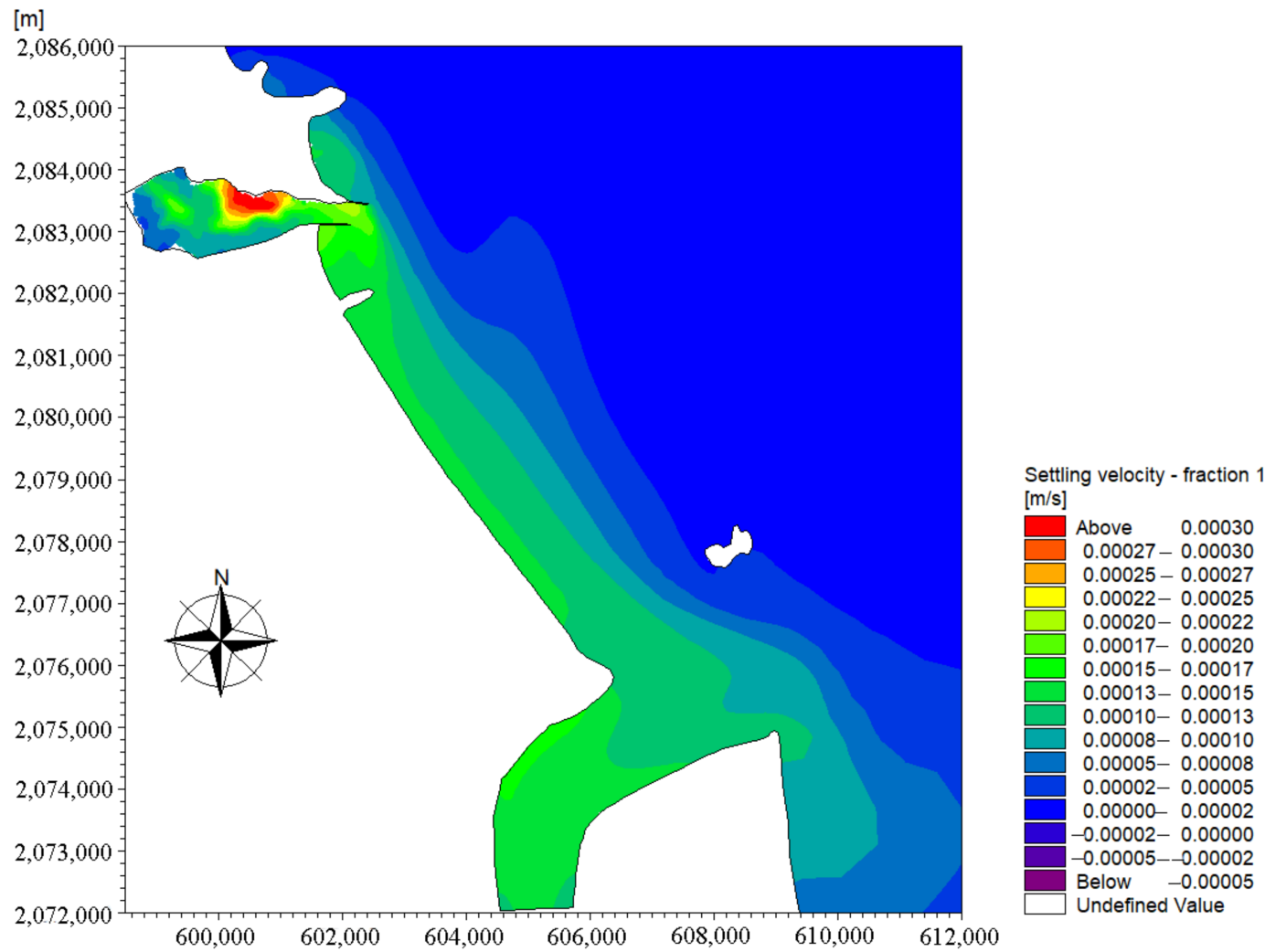

Figure 11. Distribution of settling velocity.

The $\alpha$ coefficient is a calibration coefficient that steers the exponential rise in erosion when $\tau_{b}$ rises. Parchure and Mehta stated values of the $\alpha$ coefficient from different studies to be between 4.2 and $25.6 \mathrm{~m} / \mathrm{N}^{0.5}$ [34] and van Rijn estimated values from 5 to $30 \mathrm{~m} / \mathrm{N}^{0.5}$ [33] The literature of MIKE $21 \mathrm{HD} \alpha$ usually lies between 4 and 26 [32]. In this study, the $\alpha$ coefficient has been calibrated to $5 \mathrm{~m} / \mathrm{N}^{0.5}$ for the first layer and $20 \mathrm{~m} / \mathrm{N}^{0.5}$ for the second layer.

Consolidation of the bottom sediment is not directly included in the model. However, a transition coefficient $\left(\mathrm{T}_{\mathrm{i}}\right)$ was used to determine the rate at which the sediment from upper layers is transformed to sediment at lower layers. As the layers have different characteristics as critical shear stress for erosion, the sediment will have a higher critical bottom shear stress for erosion after successively longer residence times. The value of $5 \times$ $10^{-7} \mathrm{~kg} / \mathrm{m}^{2} / \mathrm{s}$ is used for both layers.

The mud transport model was calibrated by SSC, and the result showed that RMSE were $24.15 \%$ and $17.53 \%$ for SSC at station SSC1, SSC2, respectively. The MAE were $19.26 \%$ and $14.82 \%$, respectively (Table 1 ).

A comparison of simulation results and observation data is shown in Figure 12.

To confirm the capacity of these models, the verification process was carried out based on the second simulation from 15 to 30 March 2019. The verification of Mike 21HD showed that RMSE of water level in three stations CL1, CL2, and CL3 ranged from $1.03 \%$ to $6.29 \%$ while the MAE ranged from $0.84 \%$ to $4.57 \%$. The average values of RMSE and MAE for water level were $7.38 \%$ and $7.29 \%$, respectively. A comparison of observed and simulated water levels at stations CL1, CL2, and CL3 during verification is plotted in Figure 13. 

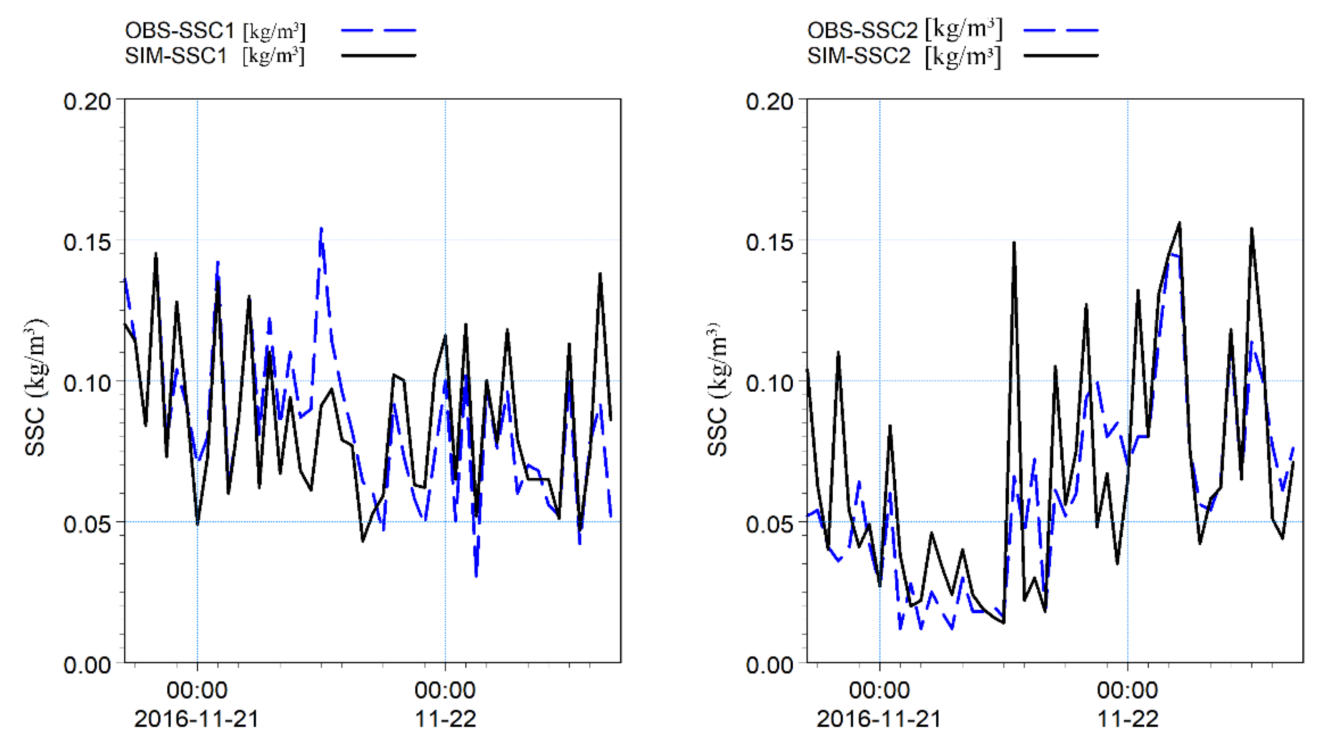

Figure 12. Comparison of observed and simulated SSC at stations SSC1 and SSC2 during calibration.
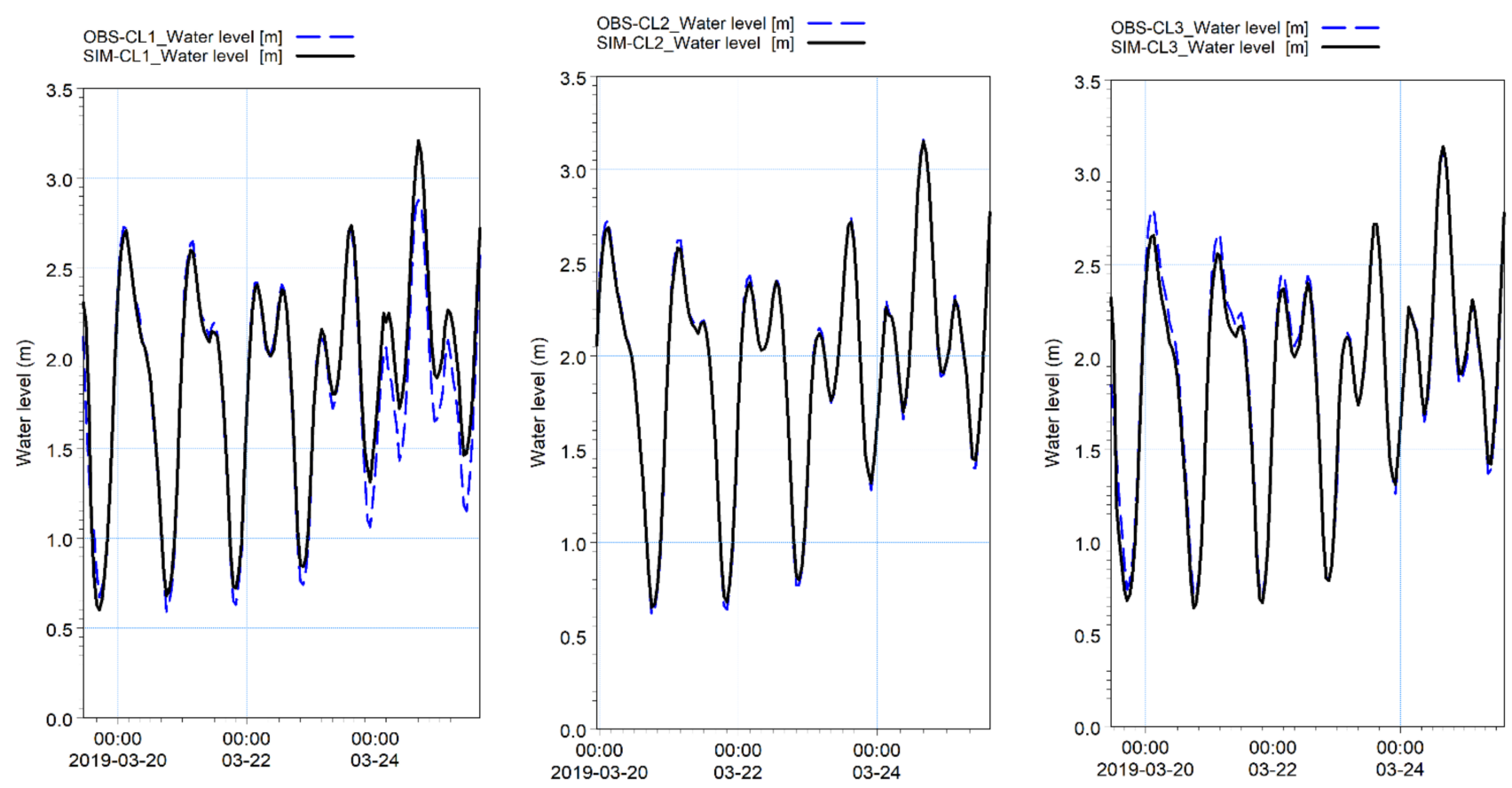

Figure 13. Comparison of observed and simulated water level at station CL1, CL2 and CL3 during verification.

The RMSE of the current speed at three stations ranged from $12.15 \%$ to $23.56 \%$ while MAE ranged from $9.34 \%$ to $19.08 \%$, the average values of RMSE and MAE for current speed were $18.81 \%$ and $15.04 \%$, respectively. The RMSE of the current direction at three stations ranged from $26.55 \%$ to $29.52 \%$ while MAE ranged from $19.51 \%$ to $23.32 \%$, the average values of RMSE and MAE for the current direction were $28.32 \%$ and $21.5 \%$, respectively (Table 2). A comparison of observed and simulated current speed and direction at station CL2, CL3, and CL4 during verification is plotted in Figures 14 and 15. 
Table 2. RMSE and MAE for model verification (from 15 to 30 March 2019).

\begin{tabular}{ccccc}
\hline Parameters & RMSE & Difference (\%) & MAE & Difference (\%) \\
\hline Water level at CL1 (m) & 0.14 & 6.29 & 0.10 & 4.57 \\
Water level at CL2 (m) & 0.03 & 1.03 & 0.02 & 0.84 \\
Water level at CL3 (m) & 0.06 & 2.58 & 0.05 & 2.08 \\
Current speed at CL2 (m/s) & 0.10 & 23.56 & 0.08 & 19.08 \\
Current direction CL2 (degree) & 93.89 & 29.52 & 74.18 & 23.32 \\
Current speed at CL3 (m/s) & 0.08 & 20.73 & 0.07 & 16.61 \\
Current direction CL3 (degree) & 93.83 & 26.55 & 68.93 & 19.51 \\
Current speed at CL4 (m/s) & 0.13 & 12.15 & 0.08 & 9.43 \\
Current direction CL4 (degree) & 64.13 & 28.89 & 48.09 & 21.66 \\
Wave height CL2 (m) & 0.15 & 11.30 & 0.12 & 9.13 \\
Wave period CL2 (sec) & 1.16 & 15.57 & 0.98 & 13.20 \\
Wave direction CL2 (degree) & 7.38 & 8.25 & 5.19 & 5.80 \\
Wave height CL3 (m) & 0.32 & 15.67 & 0.21 & 10.60 \\
Wave period CL3 (sec) & 1.73 & 19.56 & 1.56 & 17.60 \\
Wave direction CL3 (degree) & 63.72 & 18.81 & 37.73 & 11.13 \\
Wave height CL4 (m) & 0.17 & 10.34 & 0.13 & 7.98 \\
Wave period CL4 (sec) & 1.15 & 26.96 & 1.12 & 26.17 \\
Wave direction CL4 (degree) & 6.23 & 10.03 & 4.89 & 7.88 \\
\hline
\end{tabular}
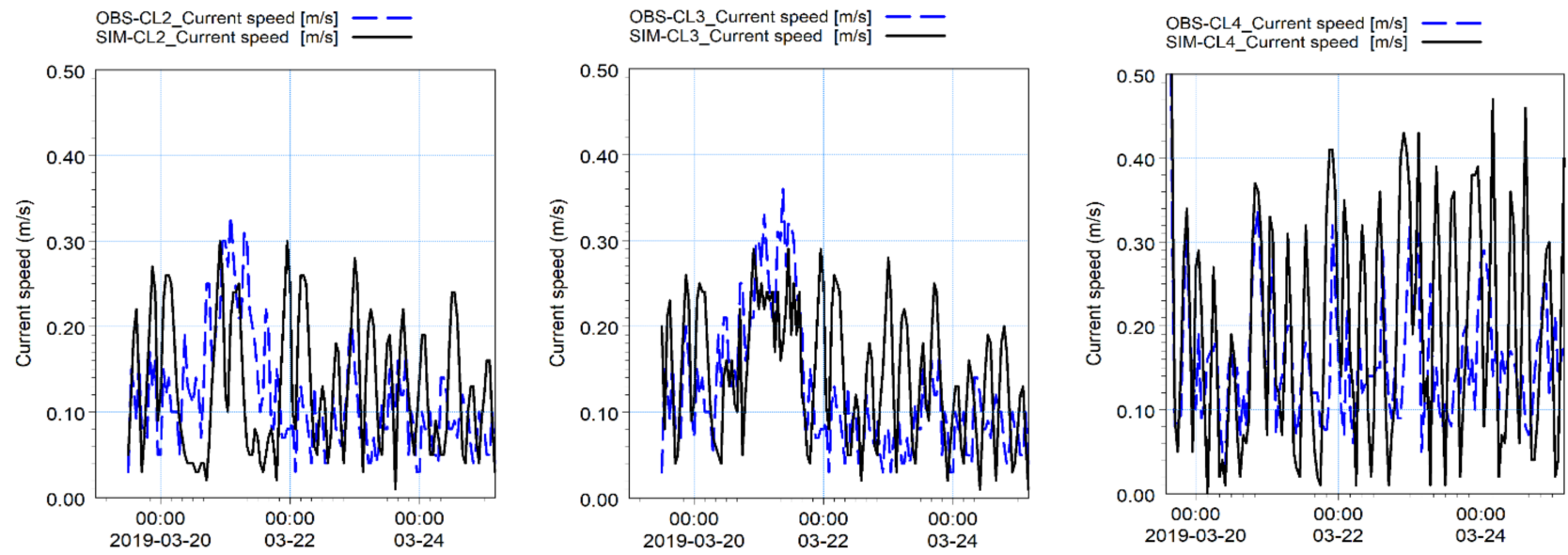

Figure 14. Comparison of observed and simulated current speed at station CL2, CL3, and CL4 during verification.
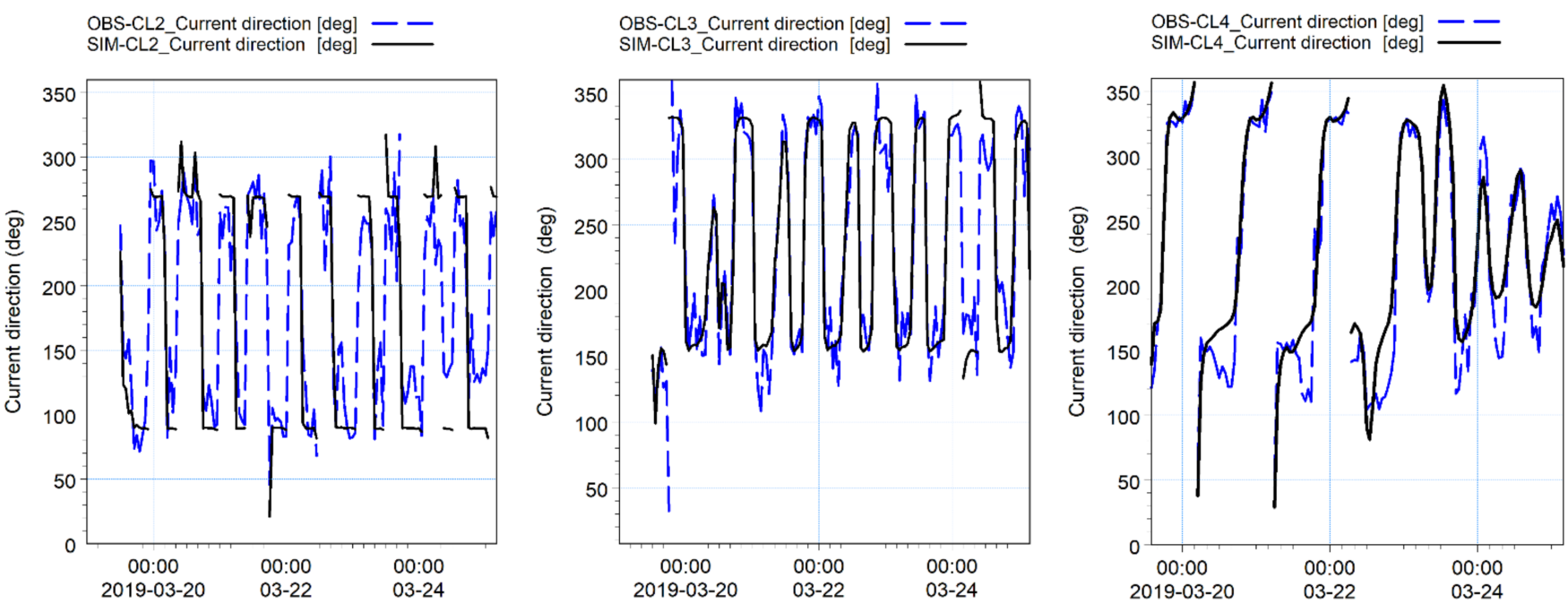

Figure 15. Comparison of observed and simulated current direction at station CL2, CL3, and CL4 during verification. 
The verification of the Mike 21SW model indicated that the RMSE of wave height ranged from $10.34 \%$ to $15.67 \%$ while MAE ranged from 7.98 to $10.60 \%$, and the average values of RMSE and MAE of wave height were $12.44 \%$ and $9.24 \%$, respectively. The RMSE of the wave period ranged from $15.57 \%$ to $26.96 \%$ while MAE ranged from $13.12 \%$ to $26.17 \%$, the average values of RMSE and MAE for wave period of $20.7 \%$ and $18.99 \%$, respectively. The RMSE of the wave direction ranged from $8.25 \%$ to $18.81 \%$ while MAE ranged from $5.8 \%$ to $11.13 \%$, and the average values of RMSE and MAE for wave direction of $12.36 \%$ and $8.27 \%$, respectively (Table 2). A comparison of observed and simulated wave height, wave period, and wave direction at station CL2, CL3, and CL4 during verification showed in Figures 16-18.


Figure 16. Comparison of observed and simulated wave height at station CL2, CL3, and CL4 during verification.
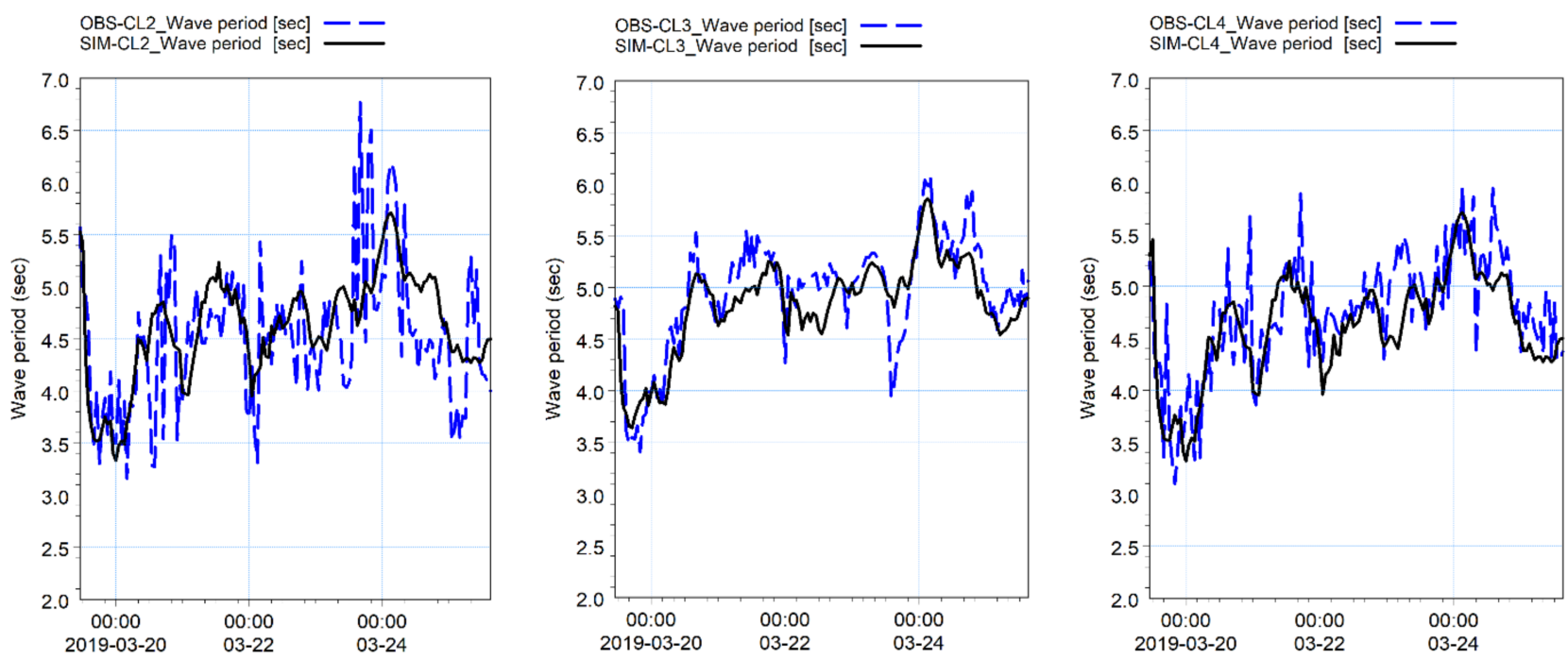

Figure 17. Comparison of observed and simulated wave period at station CL2, CL3, and CL4 during verification. 

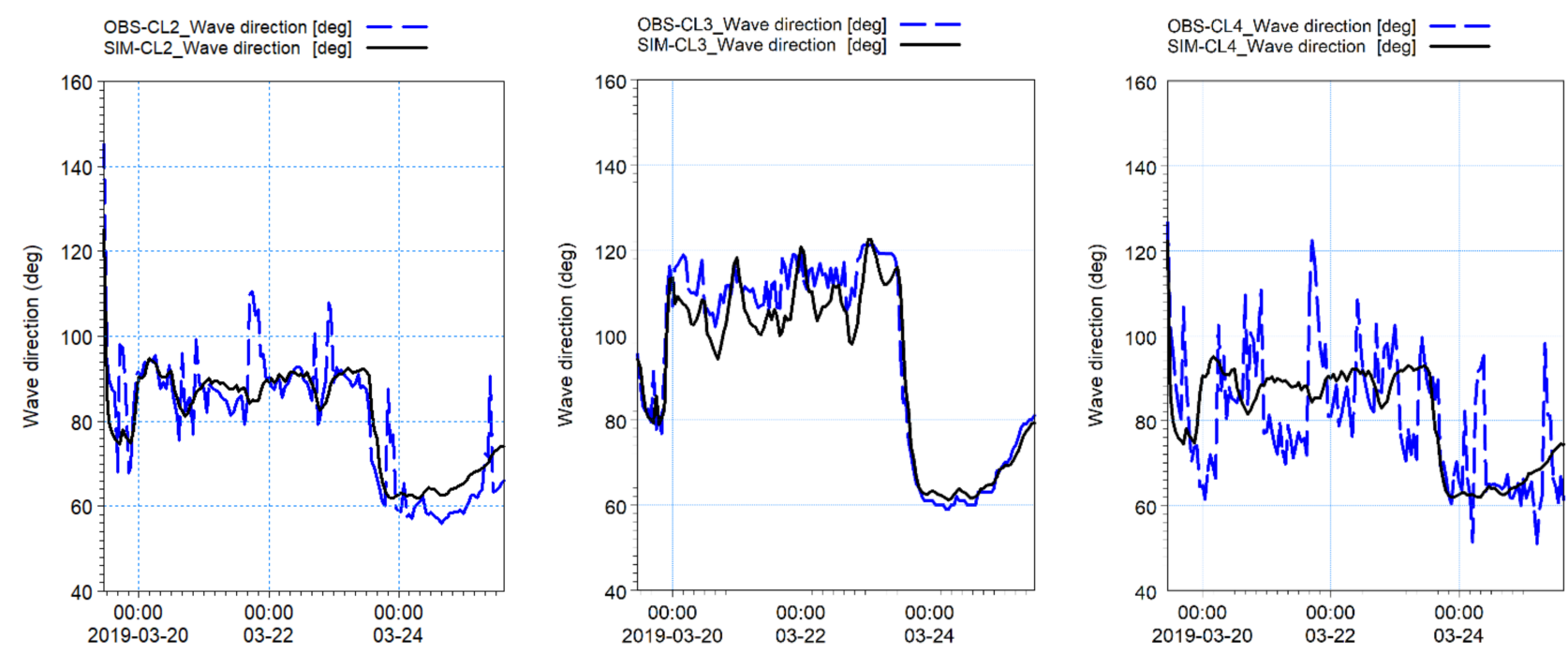

Figure 18. Comparison of observed and simulated wave direction at station CL2, CL3, and CL4 during verification.

These results indicated that the SW model was well simulated the wave transformation in the study area. These results indicate that the physical processes in the study area can be well simulated by the models.

Based on the results of model performance parameters RMSE and MAE, the calibration and verification results indicated that the models in this study are reliable because previous studies only relied on the correlation coefficient $\mathrm{R}^{2}$, some studies only compared the simulation and measurement results and without calculating any model evaluation metrics such as Lumborg and Windelin [10], Liu et al. [9], and Anh et al. [23].

\section{Results and Discussion}

\subsection{Hydrodynamic Characteristics}

Based on the HD model results, the highest tidal level in Cua Lo and Cua Hoi estuaries are $2.90 \mathrm{~m}$ and $3.15 \mathrm{~m}$ in November 2016 and March 2019, respectively. The lowest tidal level in Cua Lo and Cua Hoi estuaries are $0.65 \mathrm{~m}$ and $0.66 \mathrm{~m}$ in November 2016 and March 2019 , respectively. These results are also consistent with the observation data in the CL1 station.

During the period of NE monsoon in November 2016, the ebb current flows from the northwest (NW) to SE while the flood current flows from SE to NW (Figure 19).

The maximum ebb current in November 2016 at profile MC1 of Cua Lo estuary is 0.41 $\mathrm{m} / \mathrm{s}$ and at profile MC5 of Cua Hoi estuary is $0.39 \mathrm{~m} / \mathrm{s}$. The longshore current along Cua Lo beach has the maximum speed at headland (profile MC2) of $0.20 \mathrm{~m} / \mathrm{s}$, at profile MC3 of $0.15 \mathrm{~m} / \mathrm{s}$, and at profile MC4 near to Cua Hoi estuary of $0.16 \mathrm{~m} / \mathrm{s}$. The maximum flood current in November 2016 at profile MC1 of Cua Lo estuary is $0.36 \mathrm{~m} / \mathrm{s}$ while at MC5 of Cua Hoi estuary is $0.17 \mathrm{~m} / \mathrm{s}$ (Table 3 ).

Table 3. Maximum current speed in the study area.

\begin{tabular}{ccccc}
\hline \multirow{2}{*}{ Profile } & \multicolumn{2}{c}{ Max. Ebb Current (m/s) } & \multicolumn{2}{c}{ Max. Flood Current (m/s) } \\
& Nov-2016 & Mar-2019 & Nov-2016 & Mar-2019 \\
\hline MC1 & 0.41 & 0.51 & 0.26 & 0.40 \\
MC2 & 0.20 & 0.60 & 0.18 & 0.27 \\
MC3 & 0.15 & 0.46 & 0.12 & 0.18 \\
MC4 & 0.16 & 0.57 & 0.14 & 0.23 \\
MC5 & 0.19 & 1.09 & 0.17 & 0.40 \\
\hline
\end{tabular}




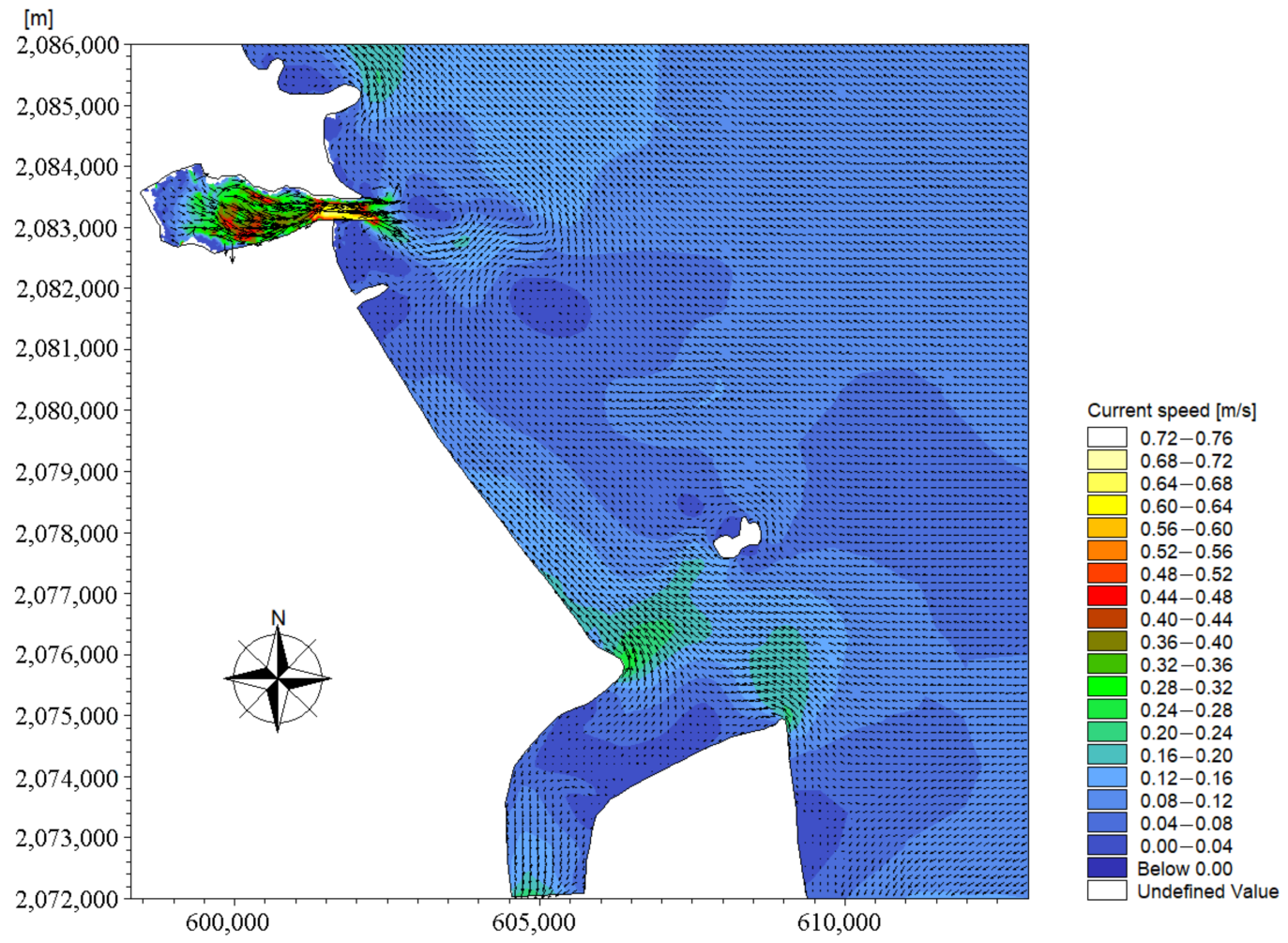

Figure 19. Ebb current field during period of NE monsoon.

The longshore current along Cua Lo beach in November 2016 flows from NW to SE in the ebb tidal and changed to the opposite direction from south to north in flood tidal (Figures 19 and 20). The maximum longshore current speed at profile MC2 is $0.18 \mathrm{~m} / \mathrm{s}$, at MC3 is $0.12 \mathrm{~m} / \mathrm{s}$, and at MC4 near to Cua Hoi estuary is $0.14 \mathrm{~m} / \mathrm{s}$ (Table 3).



Figure 20. Flood current field during NE monsoon period. 
The result of the HD model in the NE monsoon also indicated that the high current speed occurred in the estuaries due to the interaction between river flow and nearshore currents while the longshore current was slightly smaller. The tidal change in the Cua Lo estuary is sooner than in the Cua Hoi estuary.

During the period of the SE monsoon in March 2019, the ebb current flows from the SE to the NW while flood current flows from the NW to the SE (Figure 21). The maximum ebb current in March 2019 at Cua Lo (profile MC1) reached $0.51 \mathrm{~m} / \mathrm{s}$ and at Cua Hoi (MC5) reached $1.09 \mathrm{~m} / \mathrm{s}$. The longshore current along Cua Lo beach flows from NW to SE in the ebb tidal and from SE to NW in the flood tidal, and the maximum speed at headland (MC2) is $0.60 \mathrm{~m} / \mathrm{s}$, at MC3 is $0.46 \mathrm{~m} / \mathrm{s}$, and at MC4 near to the Cua Hoi estuary is $0.16 \mathrm{~m} / \mathrm{s}$ (Table 3).



Figure 21. Ebb current field during SE monsoon period.

The maximum flood current in March 2019 at MC1 of the Cua Lo estuary is $0.23 \mathrm{~m} / \mathrm{s}$ while at MC5 of the Cua Hoi estuary is $0.68 \mathrm{~m} / \mathrm{s}$. The longshore current along Cua Lo beach and the maximum speed at headland (MC2) is $0.60 \mathrm{~m} / \mathrm{s}$, at MC3 is $0.46 \mathrm{~m} / \mathrm{s}$, and at MC4 near to Cua Hoi estuary are $0.16 \mathrm{~m} / \mathrm{s}$ (Table 3 and Figure 22). It is also indicated that offshore current is large than the nearshore current in the Cua Lo estuary while in the Cua Hoi estuary the nearshore current is larger than the offshore current. This can be explained by the river flow from Cua Hoi being larger than the Cua Lo estuary. The longshore current along Cua Lo beach was smaller than the offshore current.

In the Cua Lo estuary, the current regime in the NE monsoon is very complicated when the flood current changes to an ebb current. In the Cua Lo port area, and outside of two jetties, the circulation currents exist. The southeastward flows over the northern jetty induce a cross current through the navigation channel. This phenomenon may be one of the reasons causing the back siltation in the navigation channel. The southward longshore current in the NE monsoon continues to flow over the Lan Chau rocky headland and then flows along the coast of Cua Lo beach, the longshore current combines with the offshore northwestward current to form the offshore circulation. In the SE monsoon, the circulation appearing in the south of the southern jetty tends to move northward. This 
circulation is also a reason for the cross current in the navigation channel and may result in sedimentation in the navigation channel. The interaction between the northwestward longshore current and offshore current in the SE monsoon induced a circulation (Figure 23).

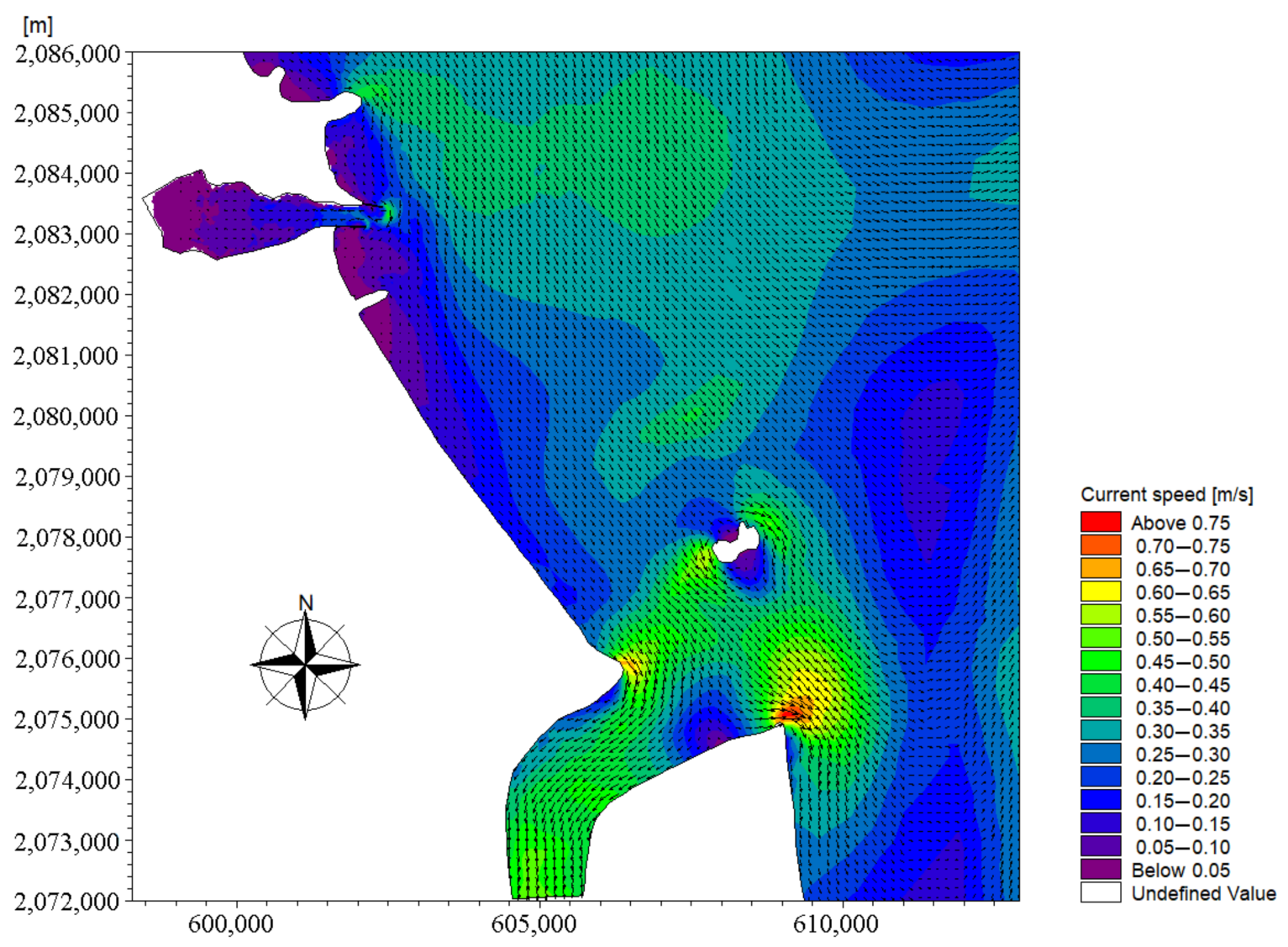

Figure 22. Flood current field during SE monsoon period.

In the Cua Hoi estuary, the current regime also shows a very complicated pattern when the flood current changes to ebb current. In the southern bank of the Cua Hoi estuary, the nearshore current speed is very small while in the northern bank the current speed is slightly larger in both NE and SE monsoon. Circulation also appears in the offshore area of the Cua Hoi estuary. In the NE monsoon, the Lam River flowed to the river mouth and divided into three components: straight to the offshore, northward, and southward, while in the SE monsoon, the river current tended northward and southward, and the current is very small in the Cua Hoi estuary's large water area. These results induced dynamic bars in front of the Cua Hoi estuary and the main reason indicated that the Cua Hoi estuary cannot provide good conditions for the construction of the deep navigation channel as well as the larger port in the Lam River (Figure 24). 

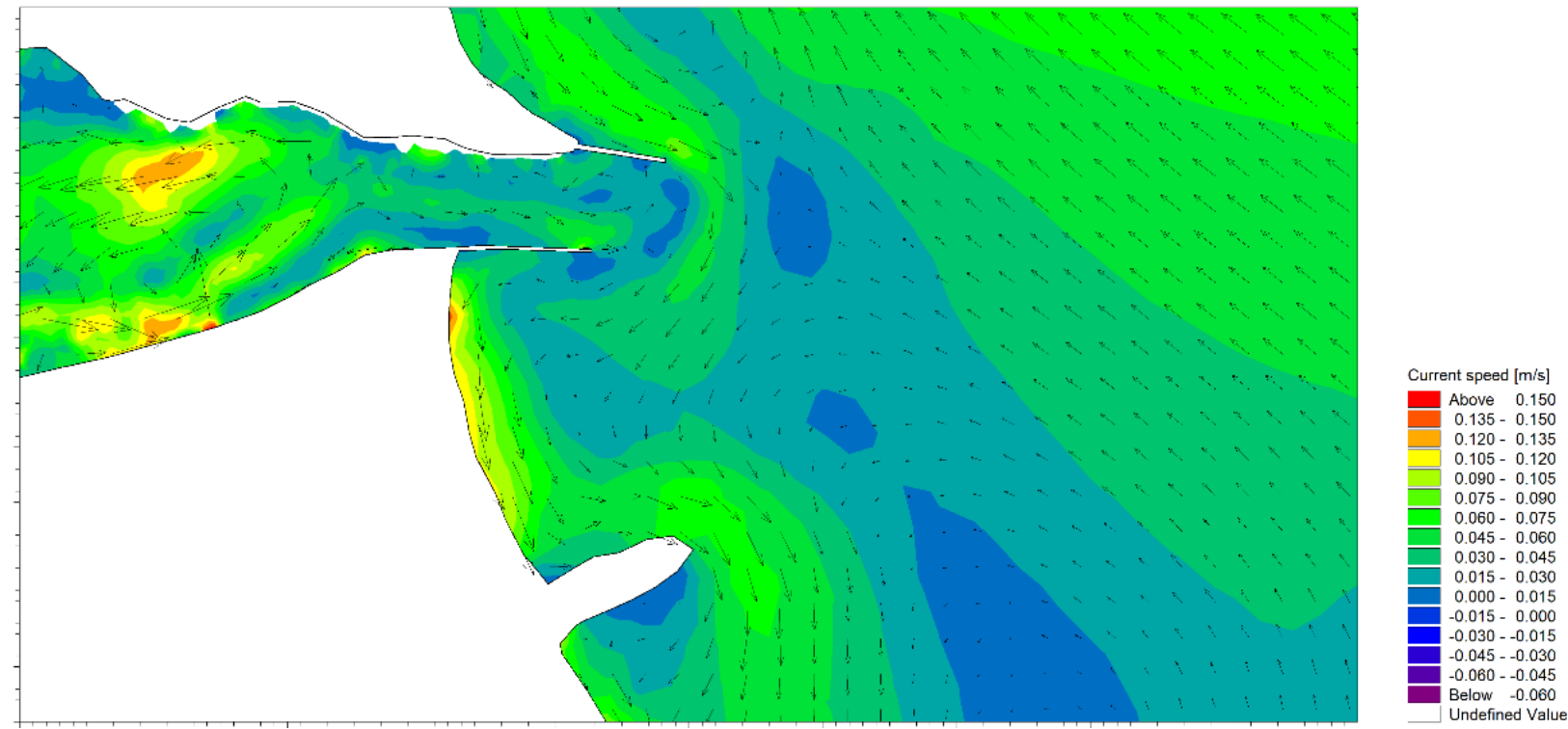

(a)
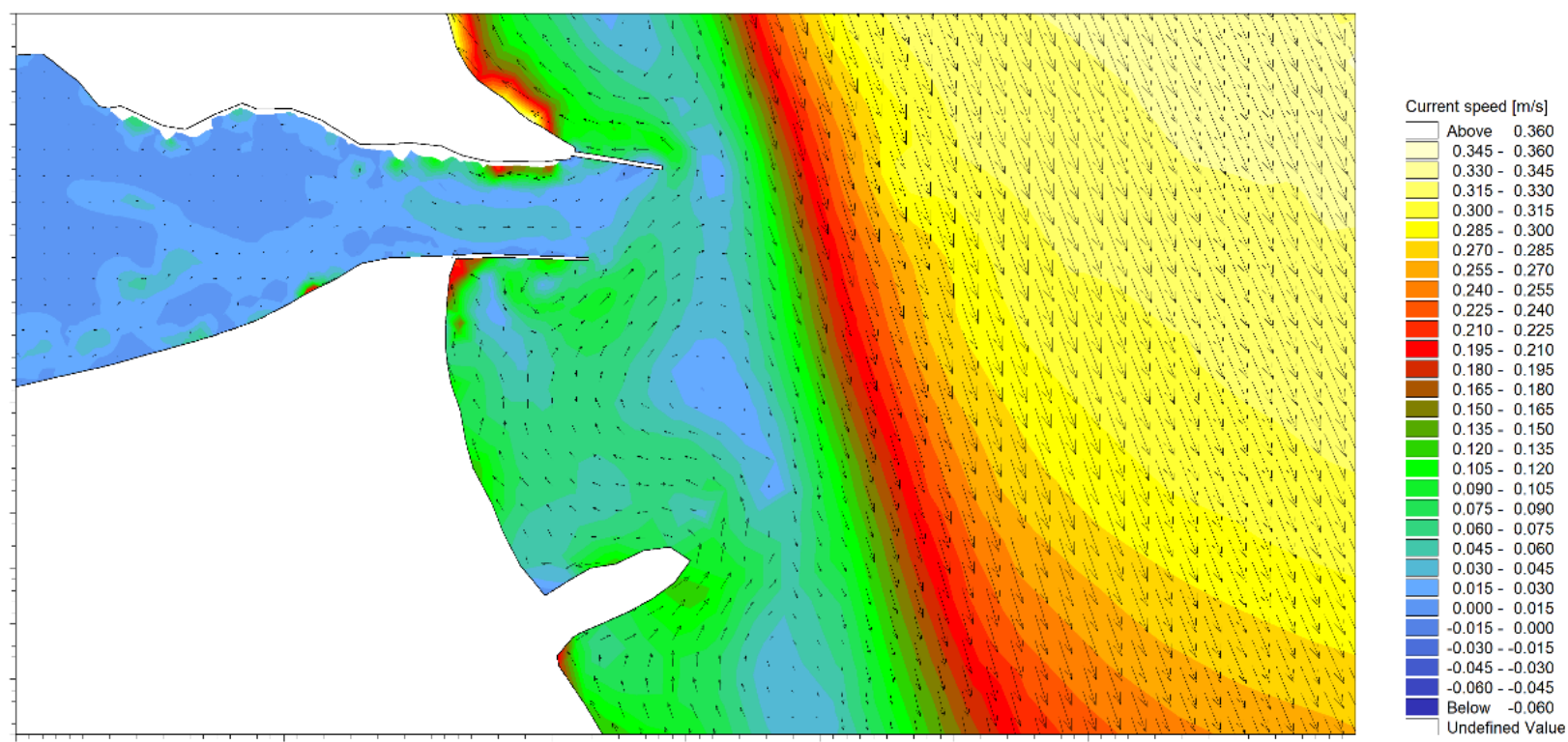

(b)

Figure 23. Current field in Cua Lo estuary during tidal change. (a) NE monsoon; (b) SE monsoon. 



(a)
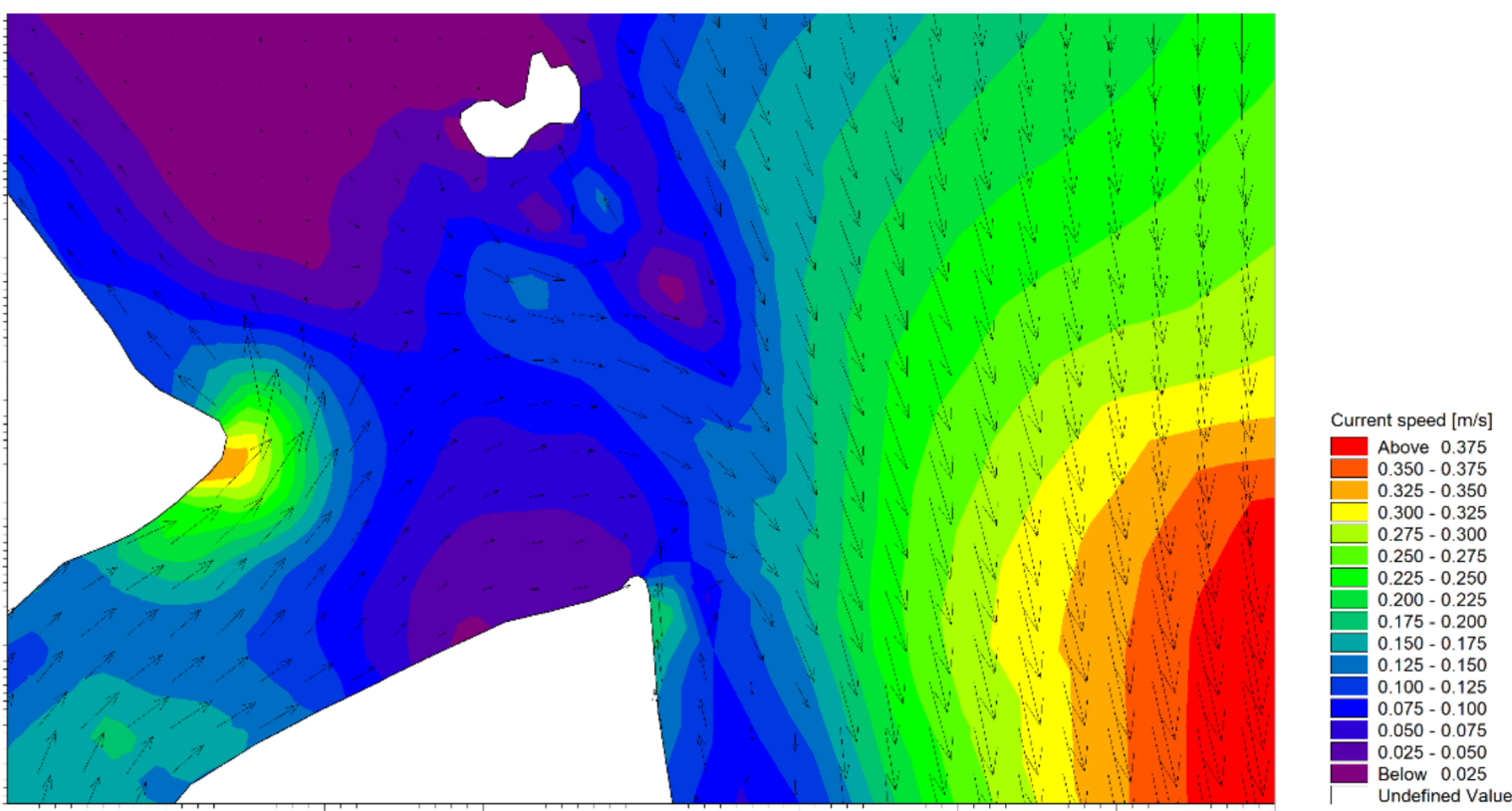

(b)

Figure 24. Current field in Cua Hoi estuary during tidal change. (a) NE monsoon; (b) SE monsoon.

\subsection{Wave Characteristics}

The result of the SW model shows that the influence of the wind's velocity field on the wave height is considerable. In the NE monsoon, waves are mainly focused on the NE, the offshore wave height can reach over $2.2 \mathrm{~m}$. In the near shore zone, the wave height decreased rapidly, it was found to be about 0.8 to $1.2 \mathrm{~m}$. In the estuaries, due to the river's flow, wave height decreased from 0.5 to $1.0 \mathrm{~m}$. The wave direction varied from NNE to NE. Hon Ngu Island in front of the Cua Hoi estuary has the role of blocking part of the NE wave from entering the estuary (Figure 25). 


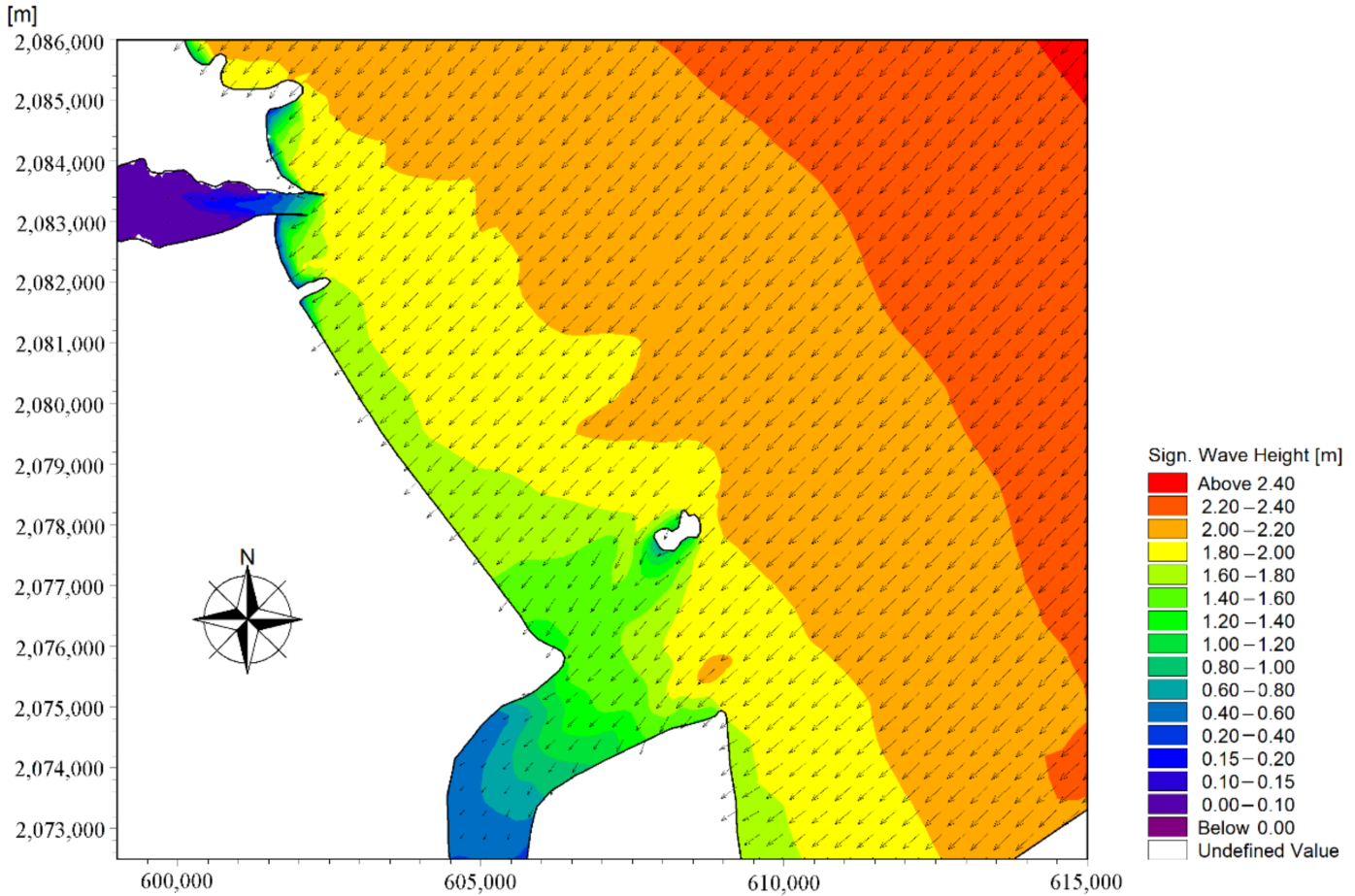

Figure 25. Wave field in NE monsoon.

Hon Ngu Island plays an important role in reducing wave height in Cua Lo beach and estuary during the SE monsoon period. The wave height is smaller, and it decreases quickly from offshore to nearshore due to the presence of Hon Ngu Island. The diffracted wave caused by Hon Ngu Island ranges from $0.4 \mathrm{~m}$ to $0.6 \mathrm{~m}$. The wave height in the Cua Hoi estuary is not influenced by Hon Ngu Island as shown in Figure 26.

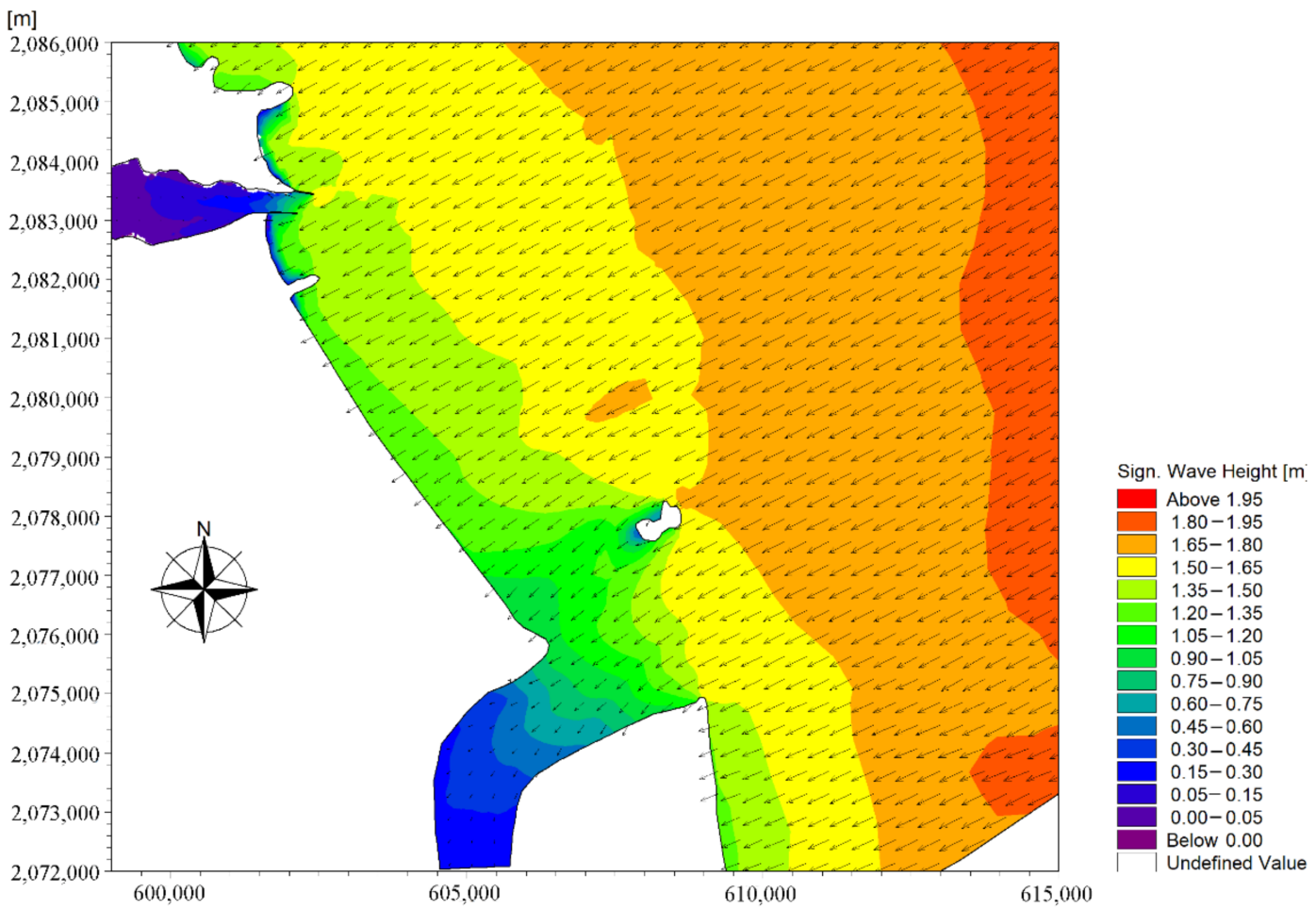

Figure 26. Wave field in SE monsoon. 
In the Cua Lo estuary, the presence of two jetties induced a slightly high diffraction wave in the gap between the two heads of both jetties. However, wave height quickly attenuated in the river mouth and became very calm in the water area of the Cua Lo port. The results also indicated that the wave height in the NE monsoon was higher than in the SE monsoon.

In both of NE and SE monsoon, the height of the waves at Cua Hoi is quite significant. This is also a factor causing instability of the shallow bar at the river mouth of Lam River.

\subsection{Sediment Transport Characteristics}

The most important parameters of the Mike 21MT model are given in Tables 4 and 5 and, which provide an overview of the input parameters.

Table 4. Inputs for bottom layers in MIKE 21 MT.

\begin{tabular}{|c|c|c|c|c|c|c|}
\hline Layer & $\begin{array}{l}\text { Density of Bottom } \\
\text { Sediment }\left(\mathrm{kg} / \mathrm{m}^{3}\right)\end{array}$ & $\begin{array}{c}\tau_{c e} \\
\left(\mathrm{~N} / \mathrm{m}^{2}\right)\end{array}$ & $\begin{array}{c}T_{i} \\
\left(\mathrm{~kg} \cdot \mathrm{m}^{-2} \mathrm{~s}^{-1}\right)\end{array}$ & $\begin{array}{c}E \\
\left(\mathrm{~kg} \cdot \mathrm{m}^{-2} \mathrm{~s}^{-1}\right)\end{array}$ & $\begin{array}{c}\alpha \\
\left(\mathrm{mN}^{-1}\right)\end{array}$ & $\begin{array}{c}\text { Initial } \\
\text { Thickness } \\
\quad(\mathrm{mm})\end{array}$ \\
\hline 1 & 300.0 & 0.20 & $5 \times 10^{-7}$ & $3 \times 10^{-6}$ to $6 \times 10^{-6}\left(^{*}\right)$ & 5.0 & $0-50\left(^{*}\right)$ \\
\hline 2 & 900.0 & 0.60 & $5 \times 10^{-7}$ & $0.4 \times 10^{-4}$ to $0.8 \times 10^{-4}\left(^{*}\right)$ & 20.0 & 500 \\
\hline
\end{tabular}

Notice: $\left.{ }^{*}\right)$ The value varies in the study domain.

Table 5. Overview of other input data in MIKE 21 MT.

\begin{tabular}{|c|c|c|}
\hline \multirow{2}{*}{ Parameter of Initial Condition and Bottom Description } & \multicolumn{2}{|c|}{ Value } \\
\hline & NE Monsoon & SE Monsoon \\
\hline SSC at upstream of Cua Lo estuary & $0.10\left(\mathrm{~kg} / \mathrm{m}^{3}\right)$ & $0.15\left(\mathrm{~kg} / \mathrm{m}^{3}\right)$ \\
\hline SSC at upstream of Cua Hoi estuary & $0.15\left(\mathrm{~kg} / \mathrm{m}^{3}\right)$ & $0.25\left(\mathrm{~kg} / \mathrm{m}^{3}\right)$ \\
\hline SSC at sea boundary & $0.01\left(\mathrm{~kg} / \mathrm{m}^{3}\right)$ & $0.01\left(\mathrm{~kg} / \mathrm{m}^{3}\right)$ \\
\hline Offshore boundary & Zero gradient & Zero gradient \\
\hline Initial SSC $\left(^{*}\right)$ & $0-0.2\left(\mathrm{~kg} / \mathrm{m}^{3}\right)$ & $0-0.2\left(\mathrm{~kg} / \mathrm{m}^{3}\right)$ \\
\hline Bed roughness & $0.001(\mathrm{~m})$ & $0.001(\mathrm{~m})$ \\
\hline$\tau_{c d}(*)$ & $0-0.45\left(\mathrm{~N} / \mathrm{m}^{2}\right)$ & $0-0.45\left(\mathrm{~N} / \mathrm{m}^{2}\right)$ \\
\hline Settling velocity coefficient & $0.48(\mathrm{~m} / \mathrm{s})$ & $0.70(\mathrm{~m} / \mathrm{s})$ \\
\hline Dispersion coefficients & $5 \mathrm{~m}^{2} / \mathrm{s}$ & $5 \mathrm{~m}^{2} / \mathrm{s}$ \\
\hline
\end{tabular}

Notice: $\left.{ }^{*}\right)$ Varies in the study domain.

The distribution of suspended sediment concentration in the study area in the NE and SE monsoon is plotted in Figures 27 and 28 and, respectively. The results show that in the SE monsoon, the maximum sediment concentration takes place in the river while in the NE monsoon it occurs around the curvature segment of the navigation channel. The SSC is concentrated in the Cua Lo estuary, ranging from 0.15 to $0.70 \mathrm{~kg} / \mathrm{m}^{3}$. In the Cua Hoi estuary, SSC ranges from 0.02 to $0.5 \mathrm{~kg} / \mathrm{m}^{3}$. The SSC along Cua Lo beach ranges from 0.25 to $0.75 \mathrm{~kg} / \mathrm{m}^{3}$, and the higher SSC is found in the north of the beach. The highest SSC found in the salt mud area is opposite with Cua Lo port.

The results of the MT model also indicate that the suspended sediment in the NE monsoon from the Cua Lo estuary can be transported into the Cua Hoi estuary and deposited in the northern bank of the Cua Hoi estuary. However, in the SE monsoon, the suspended sediment from Cua Hoi cannot be transported to the Cua Lo estuary. This may be explained by the fact that the seaward Lam River flow prevents the suspended sediment from moving across the estuary. 


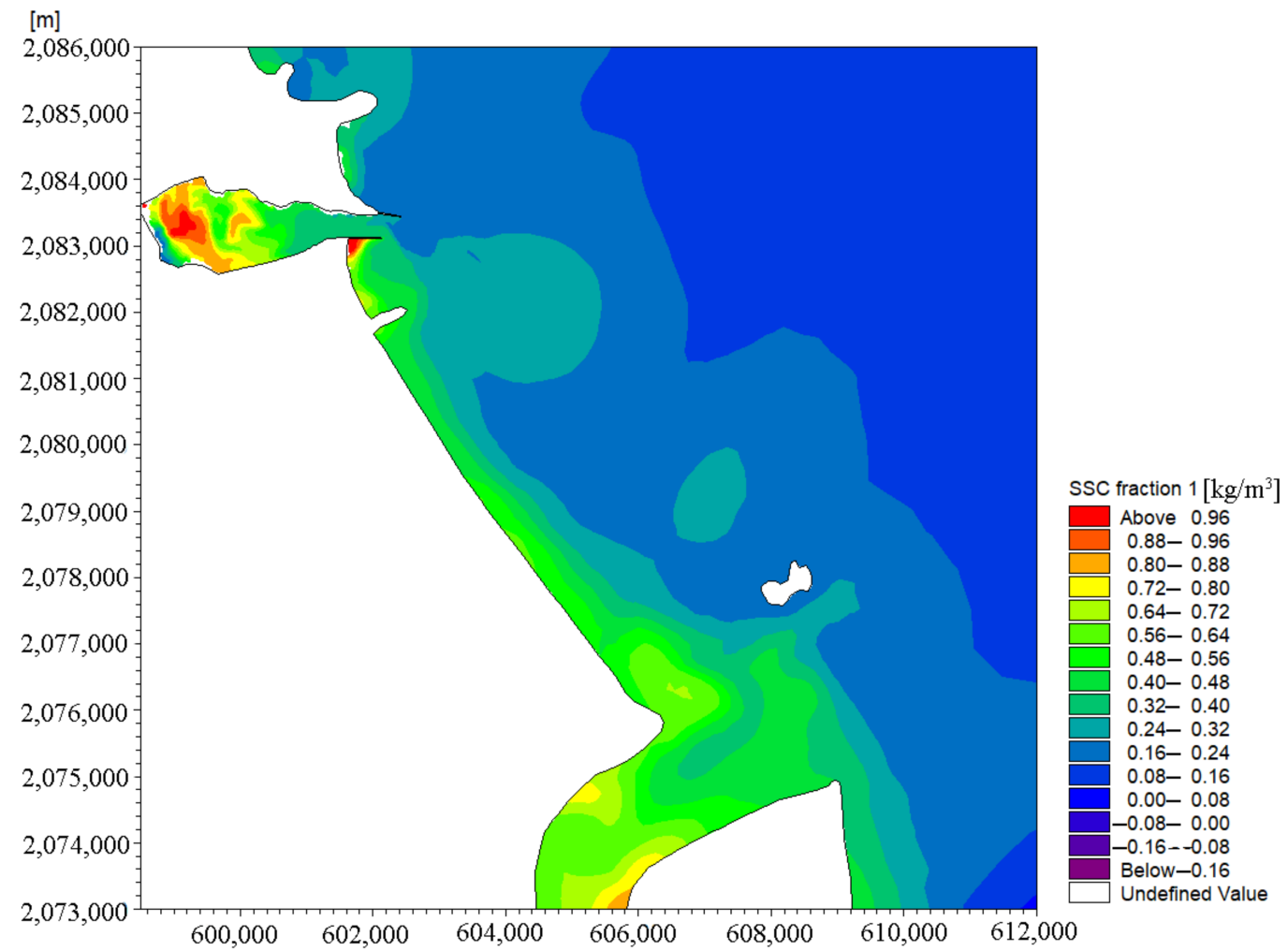

Figure 27. Distribution of SSC during NE monsoon.

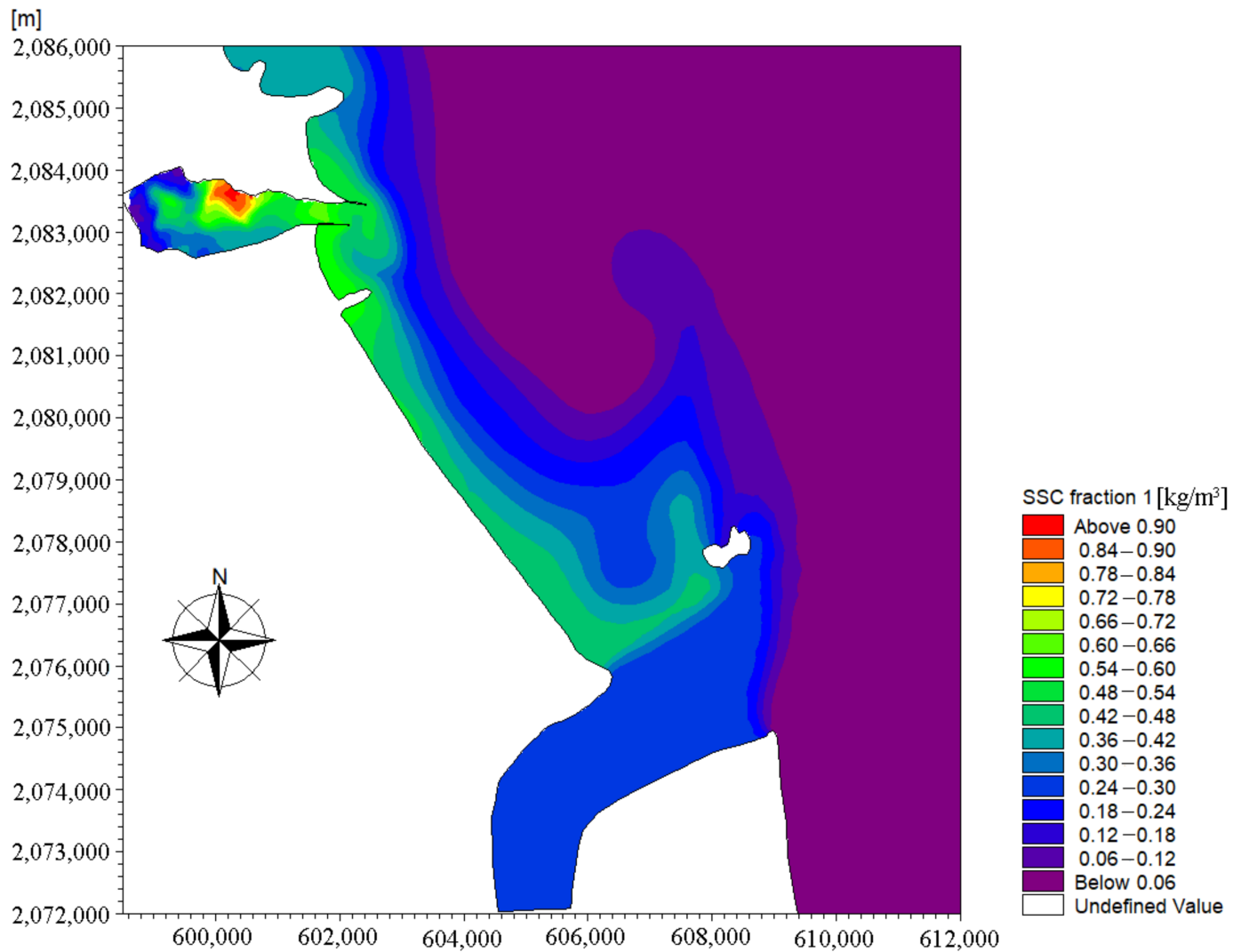

Figure 28. Distribution of SSC during SE monsoon. 
The suspended sediment in the SE monsoon from the Cua Lo estuary can move to the Cua Hoi estuary and accumulate on the northern bank of the Cua Hoi estuary. However, in the SE monsoon, the suspended sediment from Cua Hoi is unable to move to Cua Lo. This is because in the NE monsoon, the longshore current brings the sediment from Cua Lo down to the Cua Hoi estuary; when it reaches the Hoi estuary the seaward Lam River flow blocks the sediment path and induces the sedimentation at the northern bank of the Cua Hoi estuary. During the SE monsoon, the sediment from the estuaries is smaller than in the NE monsoon and also the smaller SE waves are partially covered by Hon Ngu Island, so the sediment from the Cua Hoi estuary cannot reach the Cua Lo estuary. On the other hand, the headland in the southern Cua Lo estuary has blocked a part of the longshore sediment transport from the south. Therefore, the sediment in the Cua Lo estuary in the SE monsoon is dominated by river sediment.

The bed level change in November 2016 after 15-days of simulation showed that in November 2016 the sedimentation occurred in the water area in front of Cua Lo port, in the navigation channel, and outside of two jetties while the navigation channel in the segment between two jetties and the area around the head of southern jetty were subject to erosion. Foreshore accretion occurred along Cua Lo beach in the northern bank of the Cua Hoi estuary. In the south of the Cua Hoi estuary, the south spit formed with a slightly larger area (Figure 29).

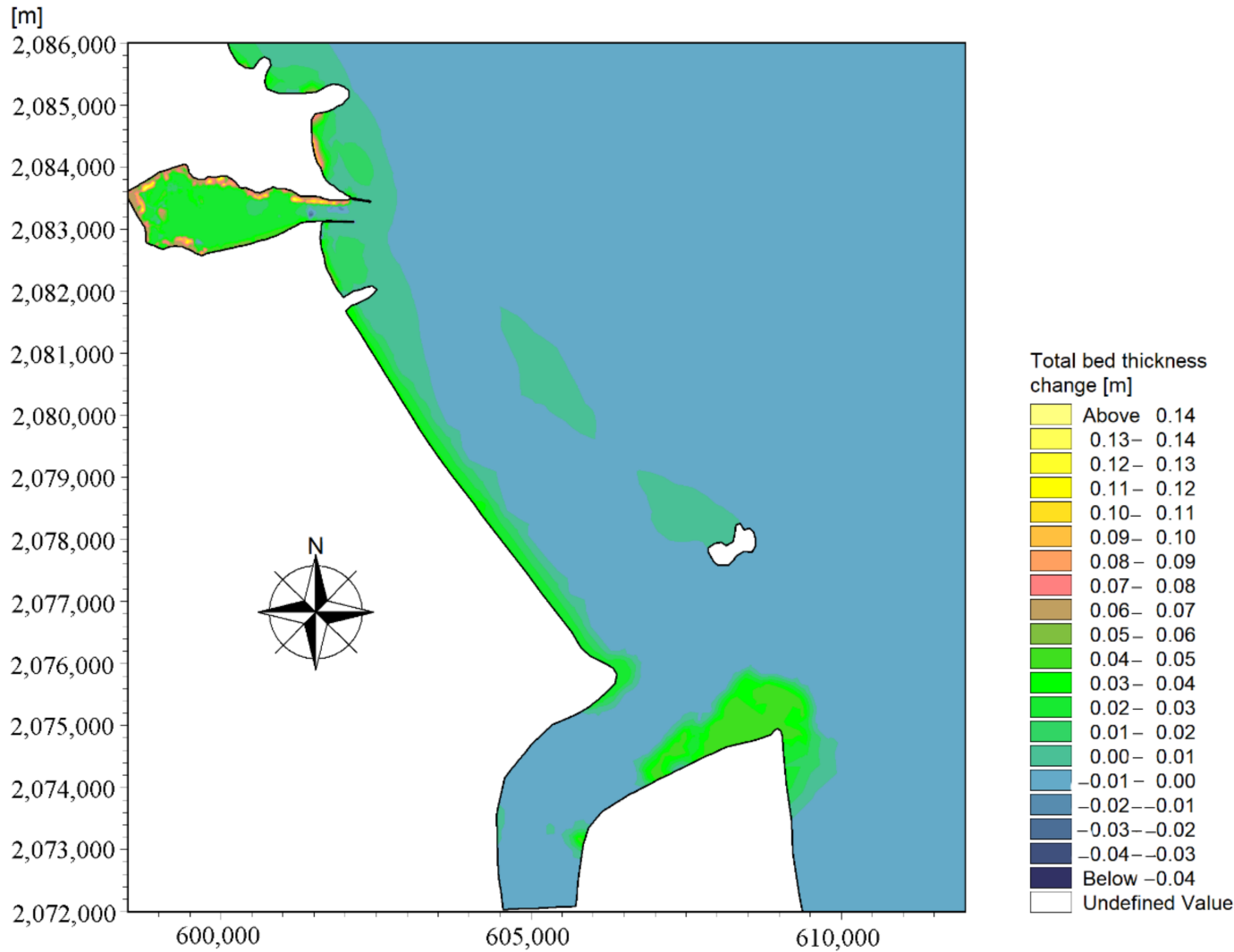

Figure 29. Bed level change in NE monsoon after two weeks of simulation.

The results of the second simulation in March 2019 indicated that the accretion only appeared in the water area of Cua Lo port, while the navigation channel to Cua Lo port was basically stable. Cua Lo beach was quite stable; in some sections of the beach, there was sedimentation but not to a great extent. In the Cua Hoi estuary, the south spit tended to grow in the NW direction, turning into the river mouth. This clearly shows that the SE wave caused the south spit to move into the estuary. The shallow bar on the northern bank of the Cua Hoi estuary occurred in SE wind as a result of the sediment transport from the river to the estuary, which was affected by river currents and waves and accumulated in 
a direction perpendicular to the estuary coast (Figure 30). The development of these two shallow bars is the main cause for the shallowness of water depth in the Cua Hoi estuary, responsible for the inability to upgrade the navigation channel to Ben Thuy port into a deep-water channel as well as to a deep-water port in Lam River.

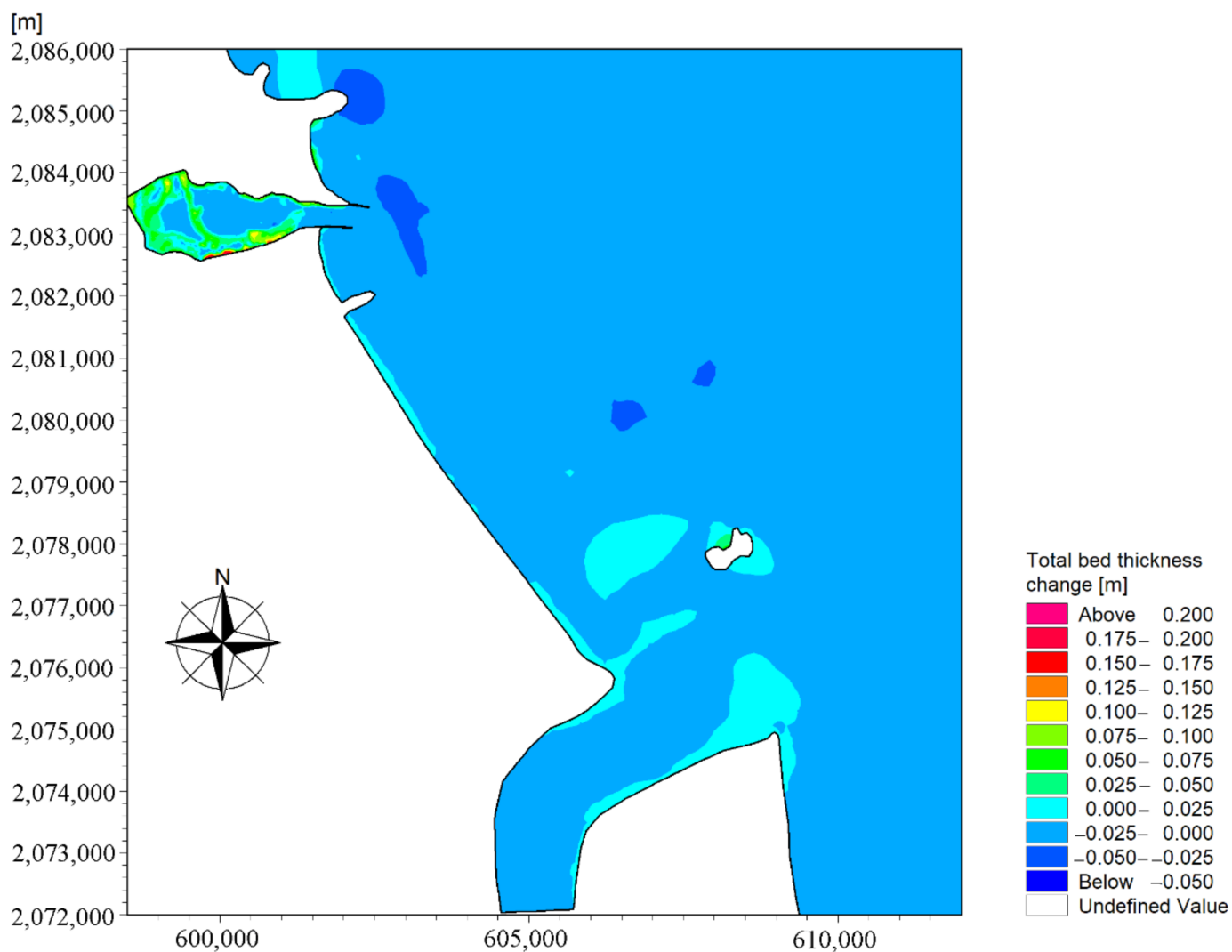

Figure 30. Bed level change in SE monsoon after two weeks of simulation.

\section{Conclusions}

In this study, a coupled two-dimensional model covering Cua Lo and Cua Hoi estuaries in Nghe An province, Vietnam was established, calibrated, and verified based on field observed data in November 2016 and March 2019. The main conclusions are drawn as follows:

(1) Nearshore currents flow from the north to the south during NE monsoon while the opposite direction from the south to the north is found during SE monsoon.

(2) The ebb and flood tides in the Cua Lo estuary occur earlier than in the Cua Hoi estuary.

(3) Wave transformation plays an important role in sediment transport in the study area. NE wave controls the sediment transport and causes sedimentation in Cua Lo port and the Cua Hoi estuary. SE wave governs the evolution of the spits in Cua Hoi estuary and has a less significant impact on the Cua Lo estuary.

(4) The water areas in front of Cua Lo port and the navigation channel to Cua Lo port show deposition during the NE monsoon. The sediment transport from Cua Lo port to the south is responsible for the growth of the shallow bar in the northern bank of the Cua Hoi estuary, but the sediment from Cua Hoi cannot be transported to the Cua Lo estuary due to the presence of Hon Ngu Island and Lan Chau rocky headland.

(5) The development of two shallow bars in the Cua Hoi estuary is the main reason for the shallow water depth in front of the Cua Hoi estuary, leading to the inability to construct a deep-water channel as well as a deep-water port in Lam River. 
Author Contributions: Conceptualization, V.T.N.; methodology, V.T.N.; software, V.T.N.; validation, V.T.N., M.T.V. and C.Z.; formal analysis, V.T.N., C.Z.; investigation, V.T.N.; resources, V.T.N., M.T.V.; data curation, V.T.N., M.T.V.; writing-original draft preparation, V.T.N.; writing—review and editing, V.T.N., M.T.V. and C.Z.; visualization, V.T.N. and M.T.V.; supervision, V.T.N. and Zhang C project administration, V.T.N.; funding acquisition, V.T.N., M.T.V. and C.Z. All authors have read and agreed to the published version of the manuscript.

Funding: This work was financially supported by The Belt and Road Special Foundation of the State Key Laboratory of Hydrology-Water Resources and Hydraulic Engineering (Grant No. 2018490811).

Conflicts of Interest: The authors declare no conflict of interest.

\section{References}

1. Moore, R.D.; Wolf, J.; Souza, A.J.; Flint, S.S. Morphological evolution of the Dee Estuary, Eastern Irish Sea, UK: A tidal asymmetry approach. Geomorphology 2009, 103, 588-596. [CrossRef]

2. Franz, G.; Pinto, L.; Ascione, I.; Mateus, M.; Fernandes, R.; Leitão, P.; Neves, R. Modelling of cohesive sediment dynamics in tidal estuarine systems: Case study of Tagus estuary, Portugal. Estuar. Coast. Shelf Sci. 2014, 151, 34-44. [CrossRef]

3. Hayter, E.; Mehta, A. Modelling cohesive sediment transport in estuarial waters. Appl. Math. Model. 1986, 10, 294-303. [CrossRef]

4. Guan, W.; Wolanski, E.; Dong, L. Cohesive Sediment Transport in the Jiaojiang River Estuary, China. Estuar. Coast. Shelf Sci. 1998, 46, 861-871. [CrossRef]

5. Guan, W.; Kot, S.; Wolanski, E. 3-D fluid-mud dynamics in the Jiaojiang Estuary, China. Estuar. Coast. Shelf Sci. 2005, 65, 747-762. [CrossRef]

6. Wu, Y.; Falconer, R.; Uncles, R. Modelling of Water Flows and Cohesive Sediment Fluxes in the Humber Estuary, UK. Mar. Pollut. Bull. 1999, 37, 182-189. [CrossRef]

7. Cancino, L.; Neves, R. Hydrodynamic and sediment suspension modelling in estuarine systems: Part II: Application to the Western Scheldt and Gironde estuaries. J. Mar. Syst. 1999, 22, 117-131. [CrossRef]

8. Cheviet, C.; Violeau, D.; Guesmia, M. Numerical simulation of cohesive sediment transport in the Loire estuary with a threedimensional model including new parameterisations. In Proceedings in Marine Science; Winterwerp, J.C., Kranenburg, C., Eds.; Elsevier: Amsterdam, The Netherlands, 2002; pp. 529-543. [CrossRef]

9. Liu, W.-C.; Hsu, M.-H.; Kuo, A.Y. Modelling of hydrodynamics and cohesive sediment transport in Tanshui River estuarine system, Taiwan. Mar. Pollut. Bull. 2002, 44, 1076-1088. [CrossRef]

10. Lumborg, U.; Windelin, A. Hydrography and cohesive sediment modelling: Application to the Rømø Dyb tidal area. J. Mar. Syst. 2003, 38, 287-303. [CrossRef]

11. Pandoe, W.W.; Edge, B.L. Cohesive sediment transport in the 3D-hydrodynamic-baroclinic circulation model. Ocean. Eng. 2004, 31, 2227-2252. [CrossRef]

12. van Kessel, T.; Vanlede, J.; de Kok, J. Development of a mud transport model for the Scheldt estuary. Cont. Shelf Res. 2011, 31, S165-S181. [CrossRef]

13. Dong, H.; Jia, L.; He, Z.; Yu, M.; Shi, Y. Application of parameters and paradigms of the erosion and deposition for cohesive sediment transport modelling in the Lingdingyang Estuary, China. Appl. Ocean Res. 2020, 94, 101999. [CrossRef]

14. Giardino, A.; Ibrahim, E.; Adam, S.; Toorman, E.A.; Monbaliu, J. Hydrodynamics and Cohesive Sediment Transport in the IJzer Estuary, Belgium: Case Study. J. Waterw. Port Coast. Ocean. Eng. 2009, 135, 176-184.

15. Wang, C.H.; Wai, O.W.H.; Hu, C.H. Three-dimensional modeling of sediment transport in the Pearl river estuary. In Proceedings of the US-China Workshop on Advanced Computational Modelling in Hydroscience and Engineering, Oxford, MI, USA, 19-21 September 2005.

16. Huan, N.M.; Trinh, N.Q.; Dat, P.T. Numerical Simulation of Sediment Transport and Morphology Changes at the Bach Dang Estuary. VNU J. Sci. Earth Sci. 2010, 26, 90-97. Available online: https:/ /js.vnu.edu.vn/EES/article/view/1779 (accessed on 10 September 2021).

17. Nguyen, V.-T.; Zheng, J.-H.; Zhang, J.-S. Mechanism of back siltation in navigation channel in Dinh An Estuary, Vietnam. Water Sci. Eng. 2013, 6, 178-188. [CrossRef]

18. Thanh, N.V. Morphological Evolution and Back Siltation of Navigation Channel in Dinh an Estuary, Mekong River Delta: Understanding, Modelling and Soluting. Ph.D. Thesis, Hohai University, Nanjing, China, 2012.

19. Vinh, V.D.; Ouillon, S.; Van Thao, N.; Tien, N.N. Numerical Simulations of Suspended Sediment Dynamics Due to Seasonal Forcing in the Mekong Coastal Area. Water 2016, 8, 255. [CrossRef]

20. Thanh, V.Q.; Reyns, J.; Wackerman, C.; Eidam, E.F.; Roelvink, D. Modelling suspended sediment dynamics on the subaqueous delta of the Mekong River. Cont. Shelf Res. 2017, 147, 213-230. [CrossRef]

21. Tu, L.X.; Thanh, V.Q.; Reyns, J.; Van, S.P.; Anh, D.T.; Dang, T.D.; Roelvink, D. Sediment transport and morphodynamical modeling on the estuaries and coastal zone of the Vietnamese Mekong Delta. Cont. Shelf Res. 2019, 186, 64-76. [CrossRef]

22. Nguyen, H.T.; Vu, C.D.; Van Nguyen, H.; Nguyen, T.D. Factors Controlling Variation in Sediment Transport at Nhat Le Estuary. In International Conference on Asian and Pacific Coasts; Springer: Hanoi, Vietnam, 2019. [CrossRef] 
23. Anh, N.D.Q.; Dien, D.C.; Tam, H.S.; Viet, N.T.; Tanaka, H. Numerical simulation of hydrodynamic and sediment transport at Cua Lo inlet, Quang Nam province, Vietnam. In Proceedings of the 8th International Conference of Physical Modeling in Coastal Science and Engineering (COASTLAB2020), Zhoushan, China, 9-12 December 2020.

24. Dien, D.C.; Tanaka, H.; Viet, N.T.; Van Manh, D. Numerical Model for Simulating Sand Terrace Formation in Front of the Cua Dai River Mouth. In Proceedings of the International Conference on Asian and Pacific Coasts, Hanoi, Vietnam, 25-28 September 2019; Springer: Berlin/Heidelberg, Germany; pp. 587-592. [CrossRef]

25. TEDIPORT. Report on Improvement Project-Investment Project to Upgrade the Navigation Channel for Vessel of 10,000 DWT Entering Cua Lo Port; TEDIPORT: Hanoi, Vietnam, 2016. (In Vietnamese)

26. Nguyen, V.T.; Do Minh, D.; Zhang, C. Effectiveness of Maintenance Dredging in the Navigation Channel of Cua Lo Port, Vietnam. In Proceedings of the 3rd International Conference on Sustainability in Civil Engineering (ICSCE 2020), Hanoi, Vietnam, 26-27 November 2020.

27. DHI, MIKE 21E3 Flow Model FM, Hydrodynamic and Transport Modulem; Scientific Documentation; DHI Water \& Environment: Copenhagen, Denmark, 2009; p. 56.

28. Soulsby, R. Dynamics of Marine Sands: A Manual for Practical Applications; Thomas Telford: London, UK, 1997.

29. Vu, M.T.; Lacroix, Y.; Nguyen, V.T. Investigating the impacts of the regression of Posidonia oceanica on hydrodynamics and sediment transport in Giens Gulf. Ocean Eng. 2017, 146, 70-86. [CrossRef]

30. Qu, T.; Mitsudera, H.; Yamagata, T. Intrusion of the North Pacific waters into the South China Sea. J. Geophys. Res. Space Phys. 2000, 105, 6415-6424. [CrossRef]

31. DHI, Spectral Wave Module, Scientific Documentation; DHI Water \& Environment: Copenhagen, Denmark, 2009.

32. DHI, MIKE 21E3 Flow Model FM, Mud Transport Module; Scientific Documentation; DHI Water \& Environment: Copenhagen, Denmark, 2009.

33. Rijn, V. Principles of Sediment Transport in Rivers, Estuaries and Coastal Seas; AQua Publications: Amsterdam, The Netherlands, 1993.

34. Parchure, T.M.; Mehta, A.J. Erosion of Soft Cohesive Sediment Deposits. J. Hydraul. Eng. 1985, 111, 1308-1326. [CrossRef]

35. Hsu, M.-H.; Kuo, A.Y.; Kuo, J.-T.; Liu, W.-C. Procedure to Calibrate and Verify Numerical Models of Estuarine Hydrodynamics. J. Hydraul. Eng. 1999, 125, 166-182. [CrossRef]

36. Dyer, K.R. Sediment processes in estuaries: Future research requirements. J. Geophys. Res. Space Phys. 1989, 94, 14327-14339. [CrossRef]

37. Krone, R.B. Flume Studies of the Transport of Sediment in Estuarine Shoaling Processes; Final Report to SanFrancisco District US Army Corps of Engineers; University of California, Berkeley: Washington, DC, USA, 1962.

38. Mehta, A.J.; Partheniades, E. An Investigation Of The Depositional Properties Of Flocculated Fine Sediments. J. Hydraul. Res. 1975, 13, 361-381. [CrossRef] 